\title{
ESTELAS FUNERARIAS DE ÉPOCA CALIFAL APARECIDAS EN ORIHUELA (ALICANTE)
}

\author{
M. ${ }^{a}$ Antonia MARTÍNEZ NúÑEZ \\ Universidad de Málaga
}

En el curso de una intervención arqueológica llevada a cabo entre los meses de marzo y junio de 1999 en un lugar situado en la Plaza Teniente Linares, en el casco histórico de la ciudad de Orihuela, aparecieron varios niveles de enterramientos de un cementerio islámico $\mathrm{y}$, entre otros materiales, tres estelas funerarias epigrafiadas.

La directora de la excavación, D. a Soledad Vélez Murcia, solicitó mi colaboración y me envió la reproducción fotográfica de las estelas, el informe preliminar de las excavaciones y todos los datos necesarios para proceder al estudio de los epígrafes. Con posterioridad he tenido ocasión de viajar a Orihuela y de observar directamente las estelas, que se encuentran depositadas actualmente en el Museo de la ciudad. Basándome, pues, en esa observación y en el citado material, he realizado la lectura y traducción de las inscripciones y su análisis epigráfico, tanto caligráfico como textual, en los que se fundamenta una valoración o conclusión final.

Por los datos de que dispongo, se trata de la primera prueba arqueológica incuestionable de la existencia de un cementerio islámico en la ciudad de Orihuela ${ }^{1}$; un cementerio ubicado intramuros de la cerca medieval de la ciudad, próximo a la Acequia Vieja de Almoradí, que hace de foso de la muralla, y a la mezquita aljama, hoy catedral, y en el que han aparecido sesenta enterramientos en varios niveles. Ni siquiera las fuentes escritas aportan datos seguros sobre la existencia de cementerios islámicos en la ciudad de Orihuela ${ }^{2}$. Aunque sí existen algunas referencias, como la que proporciona Abū Muhammad al-Rušāț̄ —nacido en Orihuela en el año 466/1074 - cuando habla de su ciudad natal y

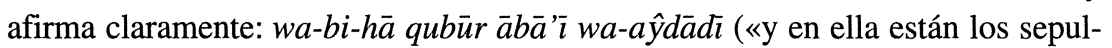

\footnotetext{
${ }^{1}$ Con anterioridad a esta excavación, sólo se habían encontrado dos sepulturas saqueadas con materiales cerámicos de superficie de los siglos VIII y IX, en unas prospecciones arqueológicas realizadas en Cabezo de Españetas, cerca del convento franciscano de Santa Ana. $C f$. Diz Ardid, E., Espacios urbanos en la Orihuela medieval, en Azuar, R., Gutiérrez, S., y Valdés, F. (eds.), Urbanismo medieval del país valenciano, Biblioteca de Arqueología Medieval Hispana, 2, Madrid, 1993, 168; y Barceló, C., La escritura árabe en el país valenciano. Inscripciones monumentales, Valencia, 1998, 52.

2 Como expone Barceló, La escritura árabe, 52.
} 
cros de mis padres y de mis abuelos») ${ }^{3}$, pero sin ninguna otra precisión. Y las noticias que nos han llegado sobre la ubicación concreta de un cementerio antiguo - frente al huerto del convento de Santa Ana, donde se encontraron las dos sepulturas antes mencionadas (nota 1) - son muy tardías ${ }^{4}$.

Con respecto a las tres inscripciones, se trata de las primeras estelas funerarias árabes que aparecen en esta ciudad y que proceden con seguridad de ella ${ }^{5} \mathrm{y}$ de ahí el interés de su estudio y publicación.

Según el informe preliminar de las excavaciones, las estelas fueron halladas en dos estructuras funerarias que han sido identificadas como mausoleos. Siguiendo la numeración otorgada por la arqueóloga en el citado informe preliminar, una de ellas, la n. ${ }^{\circ} 1$, apareció en un nivel de remoción de uno de los mausoleos (fig. 1). Las otras dos se encontraron en otro mausoleo (fig. 2), contiguo al anterior y cuya cimentación está constituida por un nivel de tumbas, algunas de ellas saqueadas, encuadradas por muros de encofrado, mampostería y sillares, formando una estructura que ha sido identificada como un panteón o qubba. La estela $n^{\circ} 2$ estaba embutida entre los sillares del muro exterior de la estructura funeraria, frente a la muralla y muy cerca de ella (fig. 3), y la n. 3 se encontró en el interior del mausoleo, descansando en vertical en el muro opuesto al antes citado y sirviendo de apoyo a la cabeza de un cadáver infantil (fig. 4).

Para la lectura, traducción y análisis de cada uno de los epígrafes he respetado la numeración que se les ha otorgado en el informe preliminar, pero debo aclarar que esa numeración no se corresponde con el orden cronológico, pues la más antigua es la . $^{\circ} 2$, seguida de la $n .^{\circ} 1$ y la $n^{\circ}{ }^{\circ} 3$. He centrado la comparación, sin duda necesaria, con otros epitafios andalusíes en los procedentes de la zona valenciana, a través del reciente, minucioso y documentado estudio de Carmen Barceló, $L a$ escritura árabe en el país valenciano. Inscripciones monumentales, antes citado.

3 Abū Muhammad al-Rušātịi; Ibn al-Jarrāt al-Išbīī, Al-Andalus en el Kitāb iqtibās al-anwār y en el Ijtiṣār iqtibās al-anwār. Ed., introd. y notas de Molina López, E., y Bosch Vilá, J., Madrid, 1990, 20.

${ }^{4}$ Diz Ardid, Espacios urbanos, 168.

$5 \mathrm{El}$ único ejemplar conservado en Orihuela, de finales del siglo XI, procede probablemente de Murcia, según Barceló, La escritura árabe, 73. A esa inscripción hay que añadir tres graffiti, ubicados en la falda del Monte de San Miguel, colindante al patio del Colegio Diocesano de Santo Domingo, que fueron publicados por Illescas, C., «Peñas Moras. Inscripciones árabes en la Sierra de Orihuela», en la revista Moros y Cristianos, del año 1982. Los textos de estos graffiti, según la transcripción del autor, son bastante extraños, pues aparece la hamdala y se menciona al Mesías, hijo de María, y a «cristianas, hijas de María», pero resulta especialmente extraña la cronología que se le otorga, año 192/808, por el uso de la hamdala como fórmula de introducción, junto al resto del contenido, y por la forma de consignar el año en el $2 .^{\circ}$ texto; con cifras seguidas de un $h \bar{a}$, abreviatura de hiŷra, lo que remitiría probablemente a una cronología tardía y tal vez a alguna comunidad de cristianos arabizados o de moriscos. Incluso puede que sean modernas, como se ha planteado acerca de uno de estos graffiti, del que se ofrece una lectura diferente en Rodríguez Martínez, L. C., «Dos inscripciones árabes modernas en montañas de Alicante», Sharq al-Andalus, 4 (1987), 388-391. 


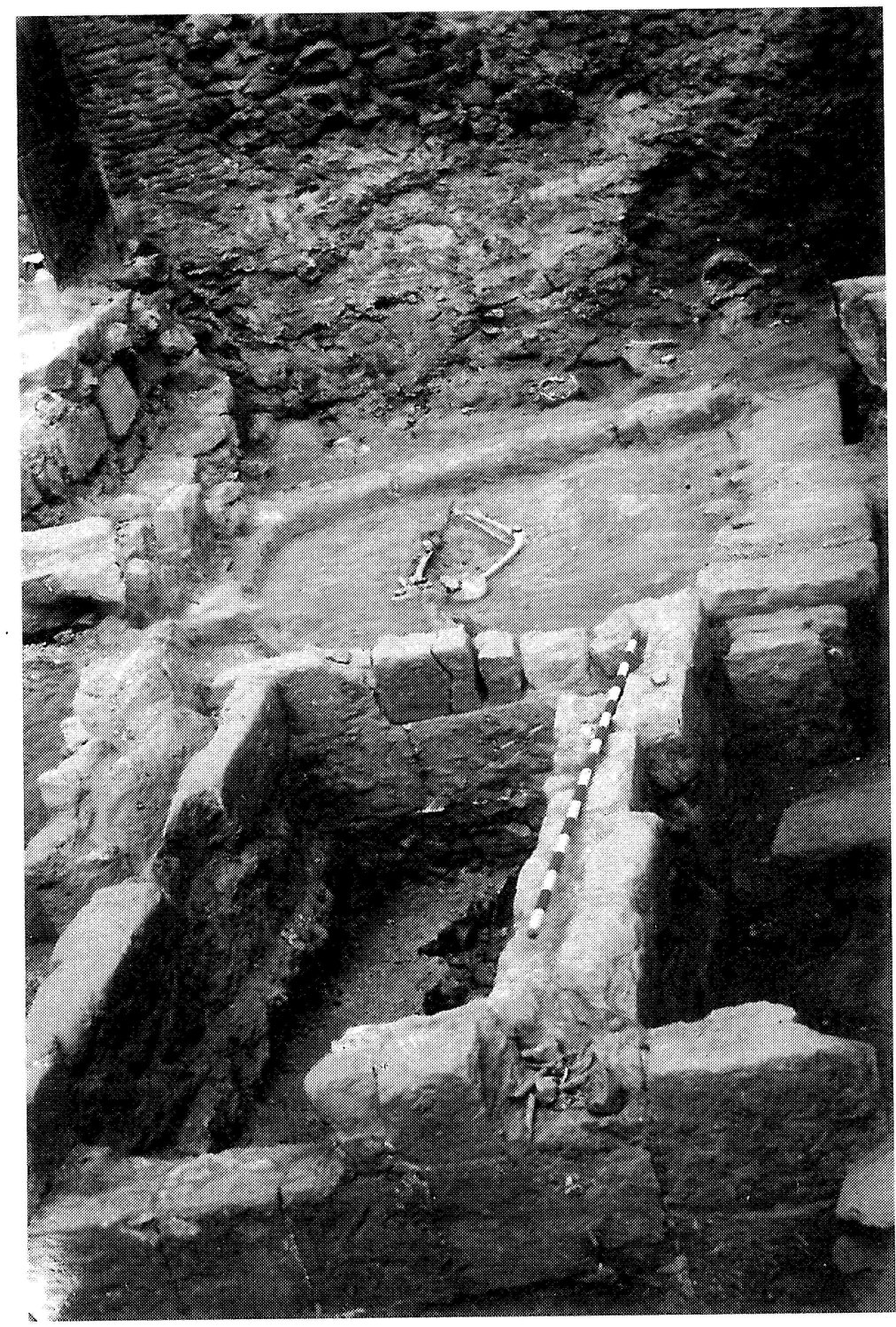

FIGURA 1. Estructura funeraria, en la parte superior de la imagen, en la que apareció la estela $n .^{\circ} 1$. 


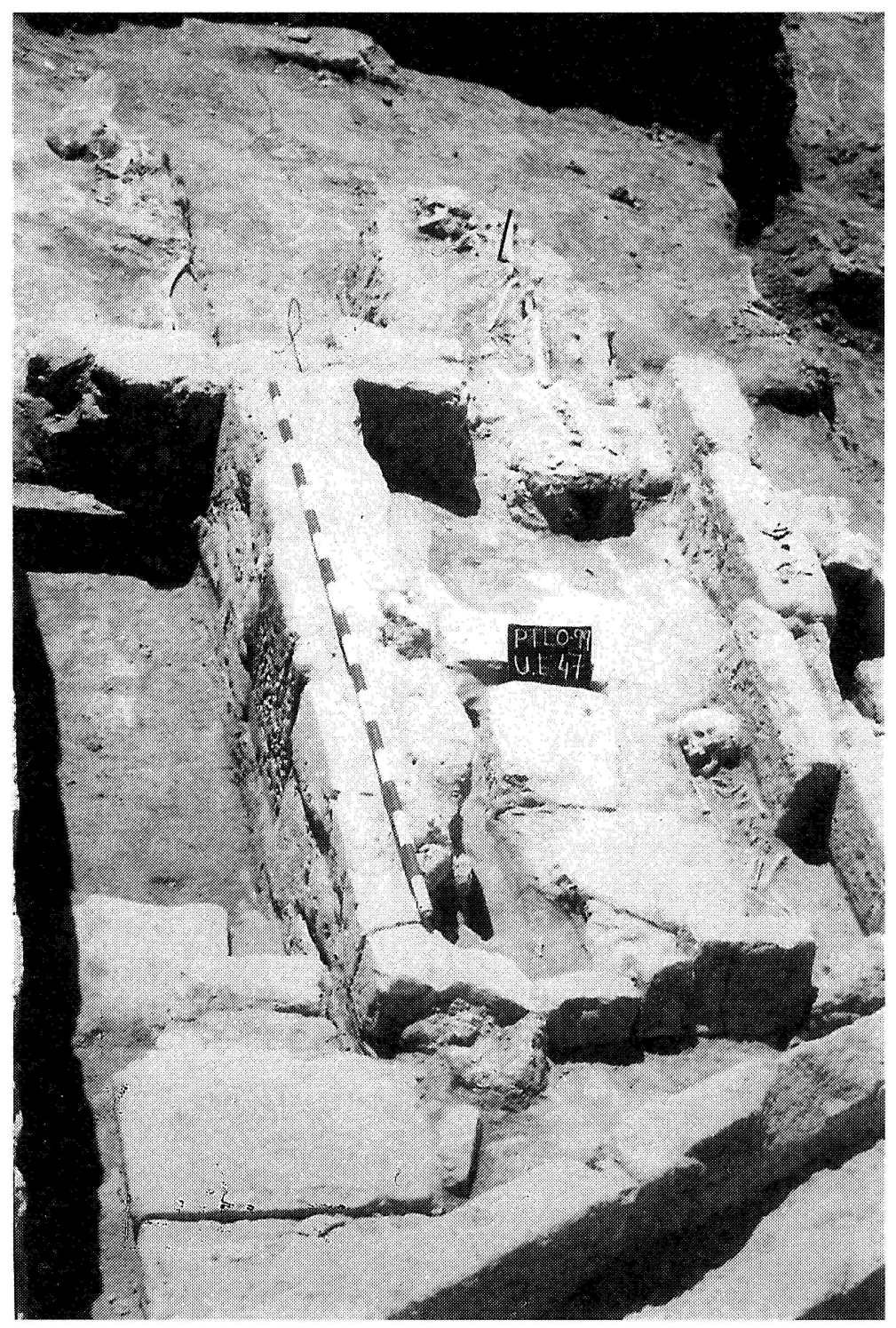

FiguRA 2. Estructura funeraria donde se ubicaban las estelas $n .^{\circ} 2$ y n..$^{\circ} 3$. 


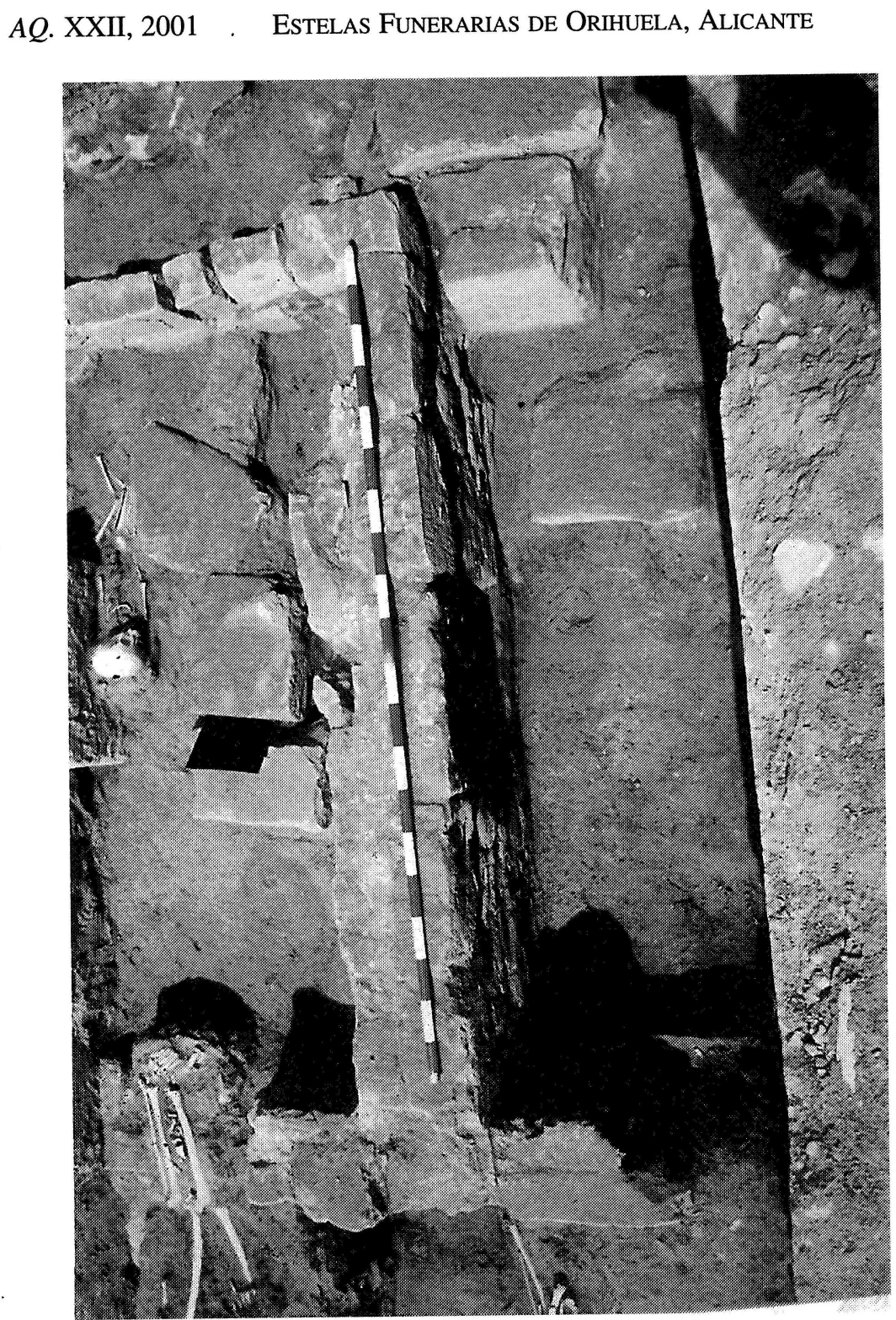

FIGURA 3. Estela n. ${ }^{\circ} 2$, embutida entre los sillares del muro exterior. 


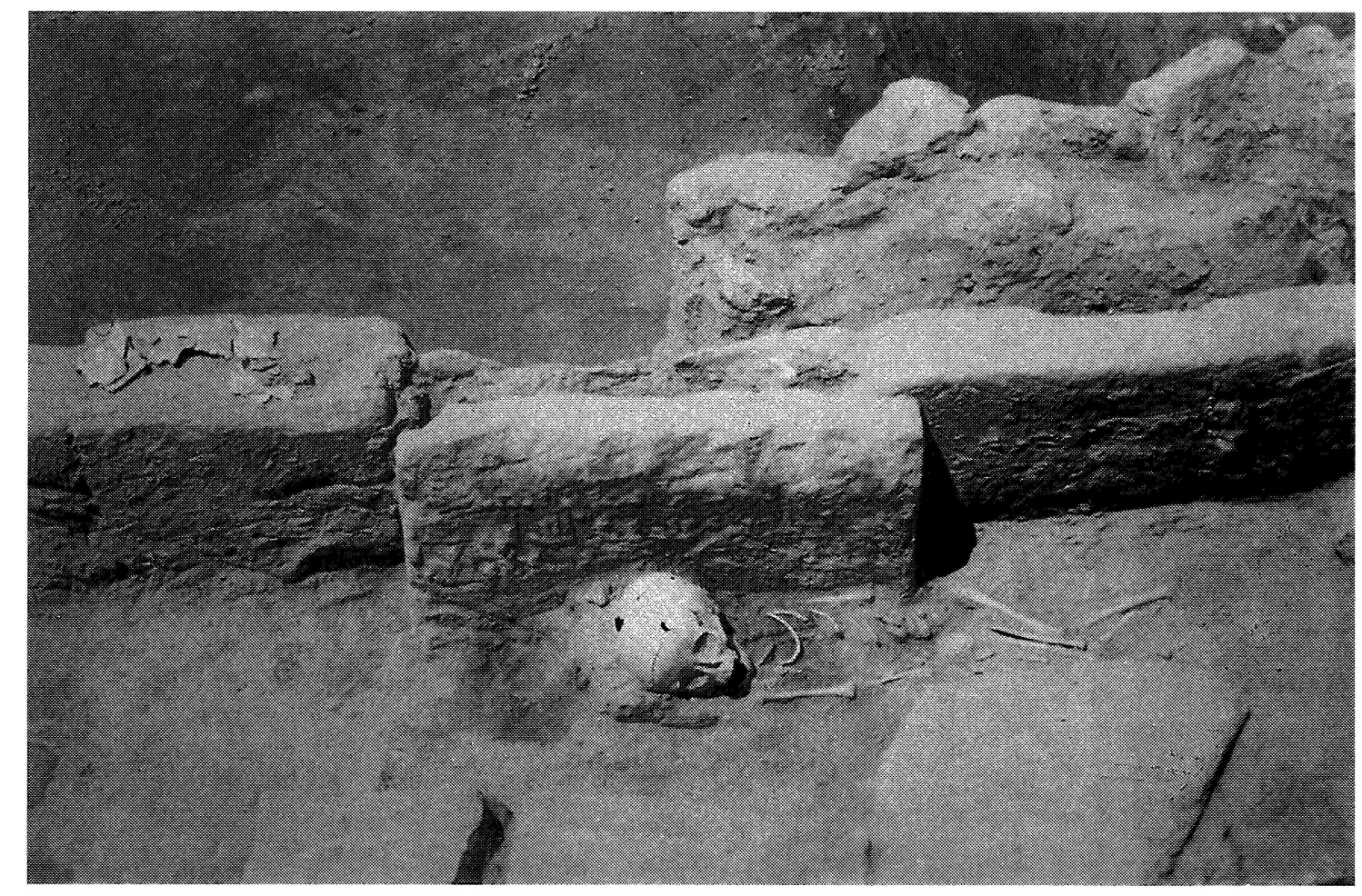

FigURA 4. Estela n. ${ }^{\circ}$, en el interior de la estructura funeraria, apoyada sobre el muro. 


\section{ESTELA N. ${ }^{\circ} 1$}

Estela de piedra arenisca, de forma rectangular, con los lados verticales más largos. El campo epigráfico, que ocupa todo el frontal de la lápida, está bordeado por un filete tallado en relieve en cuyos lados inferior e izquierdo se puede apreciar la existencia de dos acanaladuras incisas y paralelas. La estela mide $69 \mathrm{~cm}$ de largo, $52 \mathrm{~cm}$ de ancho y $14 \mathrm{~cm}$ de grosor. El filete presenta una medida máxima de 3,9 a $4 \mathrm{~cm}$ en el lado horizontal inferior y dimensiones más reducidas en los tres lados restantes (3,01 cm en el vertical izquierdo). Se conserva completa, aunque muy deteriorada en su mitad superior. Presenta restos de monocromía roja y once líneas de escritura en un cúfico austero o «arcaico», como lo denominaba Manuel Ocaña, con los caracteres tallados en relieve. Los siete primeros renglones están muy deteriorados, así como el comienzo del octavo, frente al buen estado de conservación de la parte inferior del epígrafe. En los tres últimos renglones la letra aparece más comprimida y las primeras palabras de los dos últimos están montadas sobre el filete. No obstante, se ha podido restituir la mayor parte del texto, salvo la correspondiente a la onomástica del difunto, con elementos muy gastados, e incluso algunos perdidos, cuya lectura resulta dificultosa e hipotética (fig. 5, lám. 1) ${ }^{6}$.

\section{Lectura y traducción}

$$
\begin{aligned}
& \text { 1- [بسم 1]]لله الر[حمـ]ن [الـ]ر[هيم } \\
& \text { r- الله لا اله إلا [التّ]ي [هـ] }
\end{aligned}
$$

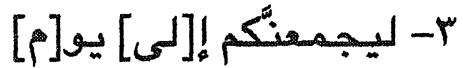

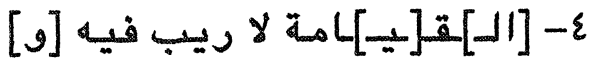

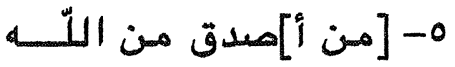

$$
\begin{aligned}
& \text { 1- حد [يثا هـ] } \\
& \text { }
\end{aligned}
$$

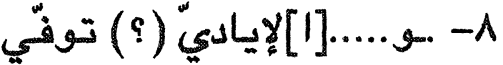

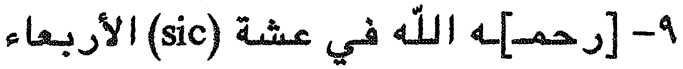

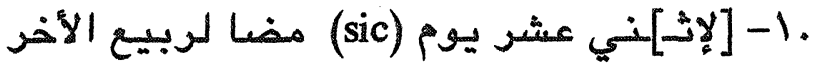

$$
\begin{aligned}
& \text { 11- [سن] [لالتة خمس وثلثين وثلاث مائة }
\end{aligned}
$$

${ }^{6}$ Los dibujos a escala han sido realizados a partir de las fotografías por J. A. Molina. 


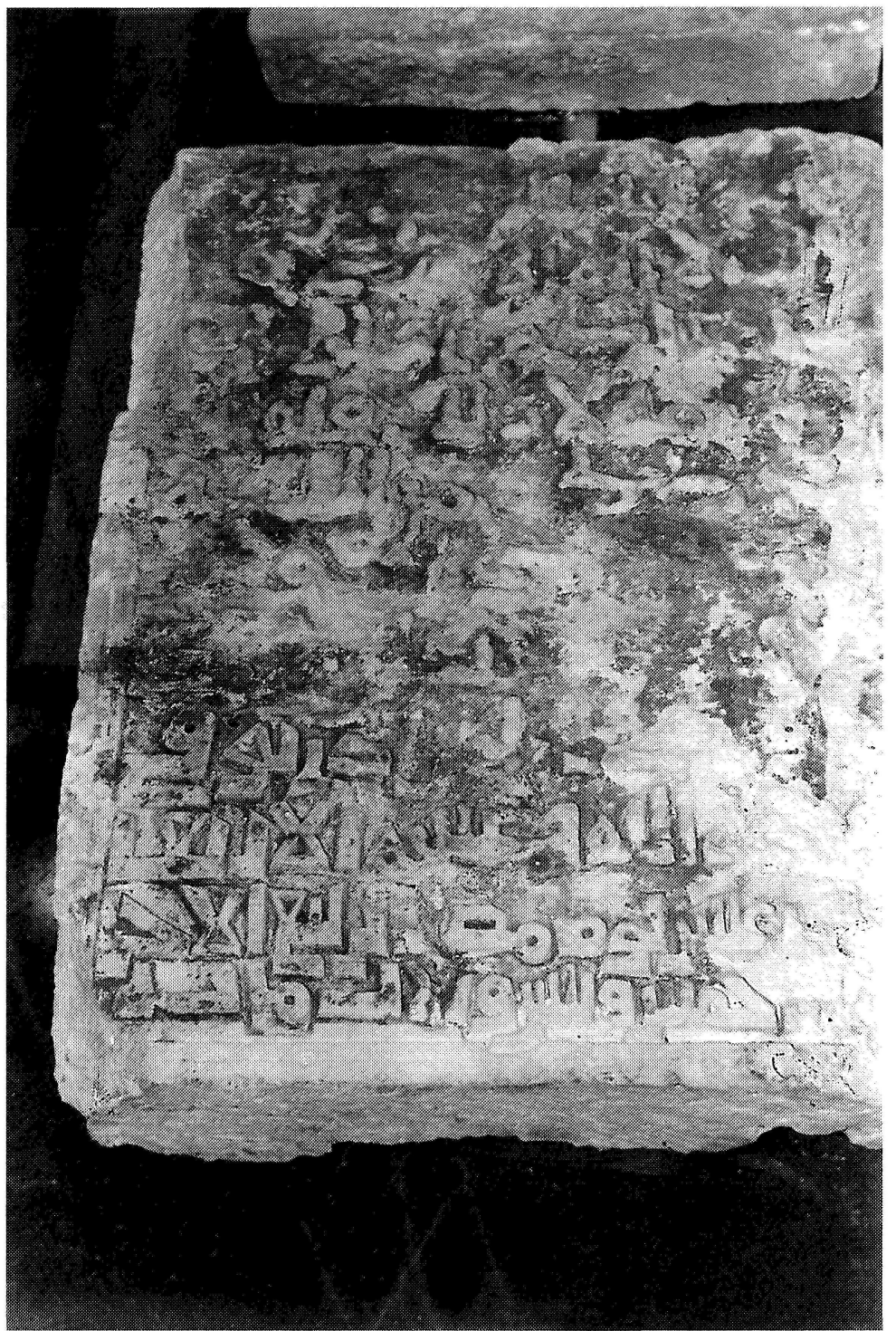

FIGURA 5. Reproducción fotográfica de la estela n. ${ }^{\circ} 1$. 


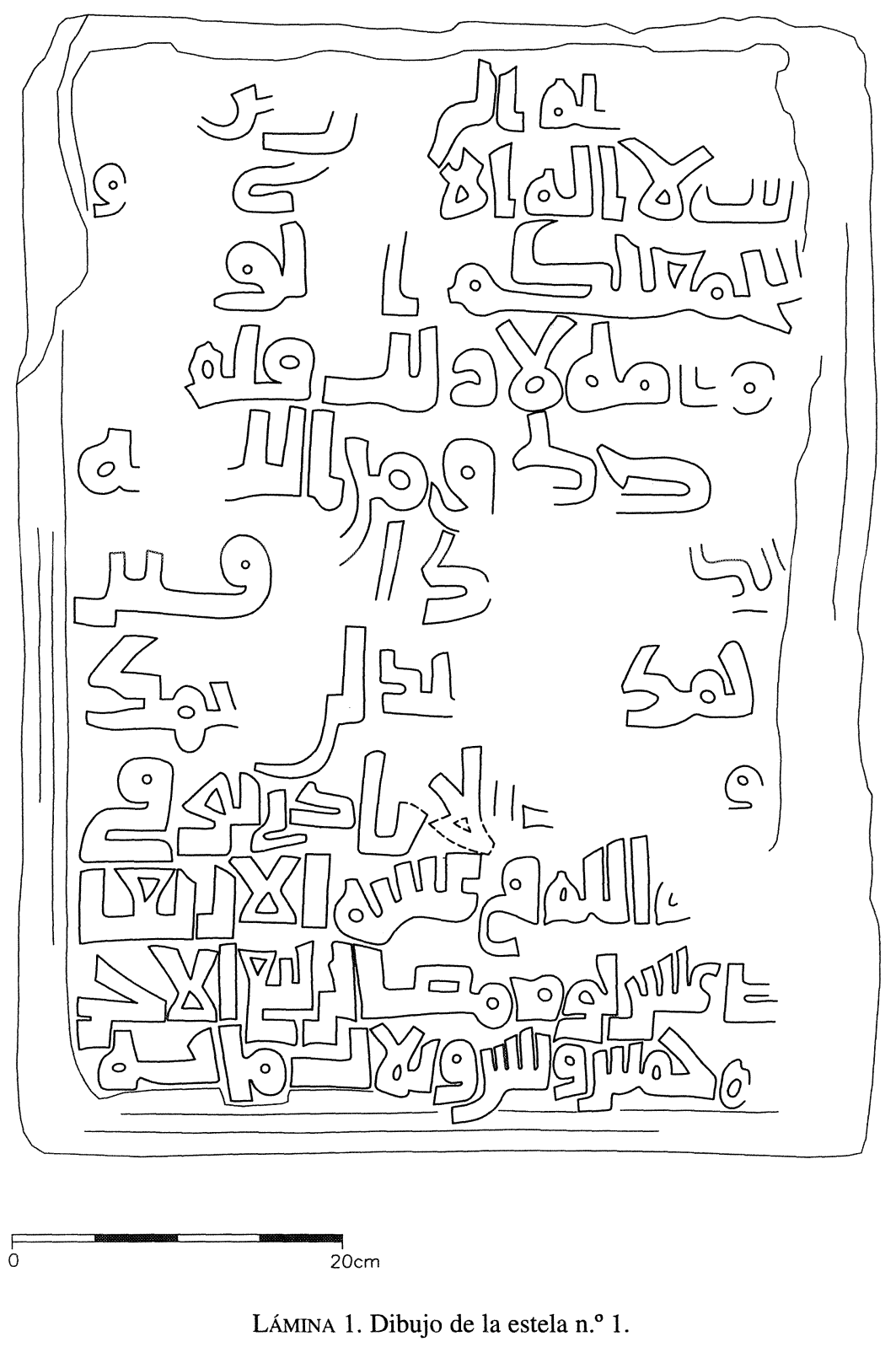


(En el nombre de) Dios, el Clemente, el Misericordioso. Dios, no hay más divinidad que Aquel que es Él (?). Ciertamente Él os reunirá el día de la resurrección, no hay duda de ello. ¿(Quién) es más verídico que Dios en cuanto a palabra? (Q. IV, 89) ...Éste es el sepulcro de Ahmad (?)...ibn Muhammad... al-Iyādì (?). Murió, Dios (se apiade) de él, en la vela del miércoles, a doce días pasados de rabī‘ al-ājir del (año) trescientos treinta y cinco (martes, 10 de noviembre del 946).

\section{Análisis caligráfico}

La inscripción presenta en general un aspecto arcaizante y bastante tosco para su cronología, que se podría concretar en los rasgos siguientes:

1) Rigurosa horizontalidad de la línea de base de escritura, sin ningún nexo curvo en la unión de los distintos grafemas.

2) Austeridad general del diseño, pues no aparece ningún remate floral o foliado en las terminaciones de las letras, ni tampoco se encuentran ornatos exentos en los huecos dejados entre los trazos altos.

3) El grafema 14f (nūn final) ha sido tallado en su versión más austera, sin prolongación ascendente.

4) Diferenciación en la altura de las trazas 2/14/17i y m y 12 i y m.

Esos rasgos generales aproximan el cúfico de esta estela al que presentan los ejemplares más arcaicos que se nos han conservado, de época emiral, antes que al cúfico de las inscripciones cordobesas califales. Y ésta parece ser una característica común a la epigrafía levantina de cronología califal ${ }^{7}$.

Ya desde el año 333H., en la inscripción fundacional del arsenal de Tortosa y en los fragmentos epigráficos de la mezquita de Madīnat al-Zahrā', se impone en la epigrafía oficial el nexo curvo en la unión de las trazas $12 \mathrm{~m}$ (lām) y $15 \mathrm{f}(h \bar{a}$ ') del término $A l l a \bar{a} h^{8}$, la identificación en la altura de $2 \mathrm{i}\left(b \bar{a}^{\prime}\right)$ y $12 \mathrm{i}$ en la basmala y la aparición de remates florales en las terminaciones de algunos grafemas, al principio y tímidamente en la figura $14 \mathrm{f}$, que se realiza ahora con terminación

\footnotetext{
7 Barceló, La escritura árabe, 118-119.

8 Con algún precedente en epigrafía funeraria, como el epitafio de una desconocida, del año 328/940, procedente de Córdoba y depositado en el Museo de Málaga. Cf. Acién Almansa, M., y Martínez Núñez, M. ${ }^{a}$ A., Catálogo de las inscripciones árabes del Museo de Málaga, Madrid, 1982, n. ${ }^{\circ}$, lám. IV, 23-24.
} 
ascendente ${ }^{9}$; diseño este último documentado en estelas funerarias cordobesas y almerienses de época emiral ${ }^{10} \mathrm{y}$ en un epígrafe conmemorativo oficial de Córdoba ${ }^{11}$, del año $329 H$. Estos cambios se afianzan, y se extienden a otros nexos y grafemas, a partir de la segunda mitad del siglo IV H., también en las inscripciones funerarias.

Aparte de estos rasgos generales, es asimismo arcaizante la forma que adopta el nexo lām-alif con la parte inferior en forma de triángulo y los trazos altos en aspa, como lo que recoge Manuel Ocaña para los años $220 \mathrm{H}$ y $241 \mathrm{H}^{12}$, correspondientes al epígrafe fundacional de la Alcazaba de Mérida y al epitafio de Gadiira, respectivamente. Sólo en un caso, y si es correcta la lectura que he propuesto, parece adoptar un diseño especial: en el término al-Iyādì (8. ${ }^{\circ}$ renglón), donde la base del triángulo es oblicua con respecto a la línea de base, y eso ha provocado que el trazo 17i siguiente se haya realizado por debajo de dicha línea. Coincide también con el cúfico arcaico el diseño de las trazas: $3 \mathrm{i}$ y m. (hāa'), $4 \mathrm{f}$ $(d \bar{a} l), 11 \mathrm{~m}(k a \bar{f}), 13 \mathrm{f}$ y a. (mìm) y $15 \mathrm{f}(h \bar{a})$, así como la factura de $A l l a \bar{h}{ }^{13}$; término este último que, en el final del renglón $5 .^{\circ}$, presenta un nexo recto muy prolongado entre los grafemas $12 \mathrm{~m}$ y $15 \mathrm{f}$, frente a la forma que adquiere en el renglón $9 .^{\circ}$. De hecho, los renglones $5^{\circ}$ y $6 .^{\circ}$ son los que presentan una grafía menos comprimida, en contraste con los tres últimos.

Hay que destacar como rasgo característico la forma que adopta el grafema $9 \mathrm{~m}$ y f. ('ayn): un triángulo con el vértice hacia abajo. En posición final este grafema recuerda al que aparece en la inscripción fundacional de la Alcazaba de Mérida ${ }^{14}$, aunque en el epígrafe de Orihuela con un diseño más anguloso en la parte superior y en el apéndice por debajo de la línea de base. Sin embargo, la posición medial, con esa misma forma triangular, se aparta de la que presenta esta traza, con la parte superior abierta, en la epigrafía cordobesa y de otras zonas de al-Andalus.

La figura 5f y a. ( $r \bar{a}$ ') se identifica con $14 \mathrm{f}$ en qabr, 'ašar o al-Raḥim, aunque adquiere un diseño más anguloso y específico en $a l$-arbi ' $\bar{a}$ ', $r a b \bar{\imath}^{\text {' }}$ y $a l-\bar{a} j i r$, mientras que ese mismo grafema en posición aislada, en el término rayb (4. ${ }^{\circ}$ ren-

\footnotetext{
${ }^{9}$ Sobre el origen de estos cambios y su evolución en la grafía cúfica oficial, $c f$. Ocaña Jiménez, M., El cúfico hispano y su evolución, Madrid, 1970, 26-35; y Martínez Núñez, M. a A., «La epigrafía del salón de 'Abd al-Raḥmān III», en Madinat al-Zahrā'. El Salón de 'Abd al-Rạ̣mān III, Córdoba, 1995, 134-138.

${ }^{10}$ Ocaña Jiménez, El cúfico hispano, 26-30; y Lévi-Provençal, E., Inscriptions arabes d'Espagne, París, 1931, n. ${ }^{\circ} 112$, pl. XXVa.

${ }^{11}$ Lévi-Provençal, Inscriptions, n. ${ }^{\circ} 5$, pl. IIa.

12 Ocaña Jiménez, El cúfico hispano, 47, fig. 9.

${ }^{13}$ Ibid., 48 , fig. 10.

${ }^{14}$ Ibid., 24, fig. 2.
} 
glón), se distingue netamente de los anteriores, pero también del trazo 14f, como en la inscripción de la Alcazaba de Mérida, hecho ya destacado por M. Ocaña ${ }^{15}$.

La traza $16 \mathrm{f}(w \bar{a} w)$, en el término tuwuffiya $\left(8^{\circ}\right.$ renglón), presenta un diseño especial, muy anguloso.

El grafema 1a (alif) a veces se presenta con ángulo recto a la derecha sobre la línea de base, diseño habitual en el cúfico arcaico, mientras que en otras ocasiones es un trazo totalmente recto en vertical.

Como rasgo gráfico más avanzado, que se aparta del diseño arcaizante, hay que señalar la altura decreciente que presentan los trazos verticales consecutivos del grafema $6 \mathrm{~m}\left(\stackrel{\text { šin }}{)}\right.$, en 'aša y 'ašar $\left(9 .^{\circ}\right.$ y $100^{\circ}$ renglón).

Otros hechos de escritura destacables son la sustitución de alif maqșüra por alif mamdūda, escritura plena en talāt y mi'a, pero defectiva en ilāha, grafías habituales en epigrafía levantina ${ }^{16}$, utilización del término 'aša por 'ašă y de yawm por el correcto yawm ${ }^{a n}$ tras el numeral itnay 'ašar.

\section{Análisis textual}

El orden de los elementos que componen el texto de este epígrafe es el siguiente:

1) Basmala.

2) Tahlil simple.

3) Cita coránica.

4) La expresión hā $\underline{d a} a \bar{q} a b r$.

5) Nombre del difunto.

6) El término tuwuffiya.

7) Eulogia rahima-hu Allāh.

8) Fecha.

Si los elementos de este formulario son los habituales en los epitafios andalusíes de ámbito urbano, el orden en el que aparecen, e incluso el contenido de alguno de ellos, son poco frecuentes para su cronología, por lo que analizaré a continuación sus aspectos más relevantes.

${ }^{15}$ Ibid., 23.

${ }^{16}$ Barceló, La escritura árabe, 100-101. 
La basmala completa, que comienza el texto, es la fórmula introductoria habitual en todos los epitafios andalusíes hasta el siglo XIII, cuando empezó a utilizarse en primer lugar la hamdala ${ }^{17}$.

A esta fórmula introductoria le sigue la šahāda en forma de tahlīl simple ${ }^{18}$ y como parte integrante de la cita coránica que aparece a continuación (Q. IV, 89), pero con una variante poco usual: lā ilāha illà alladĭ huwa, en vez de la expresión más común lā ilāha illà Allāh/huwa. Aunque en Q. IV, 89 el tahlīl aparece como lā ilāha illà huwa, en esta inscripción la última palabra legible es illà, en el renglón $2^{\circ}$, pero debido al espacio existente y a que conserva lo que parece ser el trazo 17a y el grafema $16 \mathrm{f}$ al final de ese renglón, me he inclinado por restituir allad̄i seguido de huwa.

Esta secuencia es poco habitual en los epitafios andalusíes de época califal y especialmente en los procedentes de la zona levantina, donde aparece $h \bar{a} \underline{d} \bar{a}$ qabr tras la basmala y, frente a los cordobeses, no suelen incluir la šahāda. Y así se observa en la estela funeraria más antigua, del año 331/942-43, procedente de Alpatró, Vall de Gallinera (Alicante) ${ }^{19}$. La basmala seguida de šahäda aparece, según Carmen Barceló, en algunas estelas funerarias dianenses del siglo XI, aunque esta misma autora señala un antecedente de esta tendencia, o «modificación regional», en un epitafio de Alcosser de Planes (Alicante), fechado por sus rasgos epigráficos entre los años 388-404/998-1014, y que incluye tahlìl simple y risāla simple ${ }^{20}$.

El tercer elemento del formulario es una cita coránica, exactamente la aleya 89 de la sūra IV, la cual comienza, como ya he adelantado, por el tahlīl simple. Lo destacable no es la inclusión de una cita coránica, algo usual en textos funerarios andalusíes, sino el fragmento coránico elegido en este caso, pues no está documentado hasta el momento, que yo sepa, en epigrafía andalusí ${ }^{21}$ ni en la pro-

17 Barceló, C., «Estructura textual de los epitafios andalusíes (siglos IX-XIII)», en Homenaje a Manuel Ocaña Jiménez, Córdoba, 1990, 44.

18 Sobre las variantes de la šahāda en epitafios andalusíes, cf. Barceló, Estructura textual, 47; y de la misma autora, La escritura árabe, 79. Agradezco a Carmen Barceló sus amables indicaciones sobre la posibilidad de interpretación de esta fórmula y de otros elementos de los epígrafes.

${ }^{19}$ Barceló, La escritura árabe, n. $^{\circ}$ 2, lám. Па y IIb, 126-128; y sobre la secuencia del formulario, 81 .

${ }^{20}$ Ibid., n. 9, 139-141; y sobre estelas de Denia con esa secuencia inicial, n. ${ }^{\circ} 15,16$ y 18 de los años 432/1041, 439/1047 y 445/1057, respectivamente.

${ }^{21}$ No aparece en los epígrafes recogidos por Lévi-Provençal, Inscriptions, índice de citas coránicas, 209; ni en los almerienses: Ocaña Jiménez, M., Repertorio de las inscripciones árabes de Almería, Madrid, 1964, 131; ni en los del Levante peninsular: Barceló, La escritura árabe, 257; ni en la epigrafía específicamente funeraria: Barceló, Estructura textual, 50-51. 
cedente de Qayrawān ${ }^{22}$. Y, sin embargo, el contenido sobre la resurrección de esta aleya concuerda con el de otras citas coránicas usadas con frecuencia en epitafios andalusíes.

El cuarto elemento del formulario, hād $\bar{d}$ qabr («éste es el sepulcro de»o «ésta es la tumba de»), precede habitualmente al nombre del difunto en los epitafios andalusíes, salvo en los realizados en medios rurales y en los fechados en el siglo XIII, donde este elemento desaparece y la mención del difunto va precedida de tuwuffiy ${ }^{23}$. Por otra parte, y como ya he mencionado, en esta estela no se sitúa tras la basmala, como parece ser lo más frecuente hasta el final del califato.

En cuanto al nombre del difunto, la lectura propuesta es hipótetica en algunos de sus extremos, debido al mal estado de conservación de esa parte de la inscripción. He restituido, por el espacio disponible al comienzo del $7 .^{\circ}$ renglón, la lectura del ism del difunto, Ahmad, supliendo el trazo 1a perdido. Al final de ese mismo renglón se consigna el nasab, que es, sin duda, ibn Muhammad, precedido de los grafemas $2 \mathrm{i}$ o m. y 4f, que pueden corresponder al final de otro nasab con algún nombre como Walid, Sa ìd, Jālid, Zayd, Yazìd, etc. Y en el renglón siguiente creo que ha de leerse la nisba, al-Iyāali, antes de tuwuffiya. Si la última parte de la nisba se conserva y pueden observarse sus trazos con nitidez, no sucede lo mismo con la parte inicial, muy deteriorada, en la que se aprecia el artículo, un trazo oblicuo a la línea de base, un grafema por debajo de la línea de base y un alif. En principio, estos elementos conducirían a la lectura siguiente: artículo seguido de los grafemas $3 \mathrm{~m}, 5 \mathrm{f}$ y 1a, resultando una nisba del tipo al-

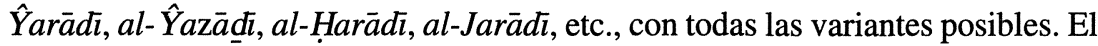
hecho de decantarme por la lectura al-Iyā dì se debe, aparte de no haber podido documentar de manera convincente las posibilidades anteriores, a los siguientes motivos: a) el trazo oblicuo está fragmentado en su parte inferior, pero permanece una impronta dejada en la piedra, que considero la forma triangular del nexo lām-alif, y no hay restos del nexo de unión con el grafema siguiente; b) este grafema, escrito por debajo de la caja del renglón, lo he identificado con un trazo $2 / 17 i\left(y \bar{a}^{\prime}\right)$ porque difiere de las figuras que adopta el trazo $5 \mathrm{f}$ en este epígrafe, especialmente del que se ubica en lo que sería la misma secuencia, en al-äjir (final del $10 .^{\circ}$ renglón), y porque parece que va unido al 1f (alif) siguiente, también muy deteriorado en su parte inferior.

${ }^{22}$ Cf. Roy, B., y Poinssot, P., Inscriptions arabes de Kairouan, vol. II, fasc. 1, París, 1950, 105110; y Zbiss, S. M., Nouvelles inscriptions arabes de Kairouan. Corpus des inscriptions arabes de Tunisie, 3. a parte, Túnez, 1977, 7-19.

${ }^{23}$ Barceló, Estructura textual, 45-46. 
Esta nisba, al-Iyādì, sí está documentada y hace referencia a una antigua tri-

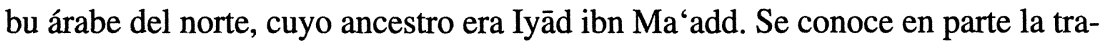
yectoria de los Banū Iyād durante la etapa preislámica y su oposición primera, en el norte de Siria y en Irak, a las conquistas islámicas. A partir de entonces, y tras su islamización, las noticias son escasas, aunque se sabe, entre otras cosas, que algunos Iyādíes llegaron a al-Andalus y que entre ellos se encontraba la célebre familia de los Banū Zuhr, en Sevilla ${ }^{24}$.

Ibn Ḥazm, en la ŶYamhara, menciona a los Banū Iyād ${ }^{25}$, se refiere a los descendientes de Iyād ibn Ma'add y afirma que en al-Andalus se instalaron en Carmona y Niebla: wa-dāru-hum bi-l-Andalus Qarmūna wa-Labla ${ }^{26}$. Por su parte, al-Rušāțị ${ }^{27}$ menciona a un tal Jațtāb por las nisba/s de al-Iyād $\bar{\imath}$ —al-Ayād $\bar{\imath}$, para los editores del texto- y al-Qarmūni, lo que redunda también en el dato aportado por Ibn Hazm.

De ser acertada la lectura propuesta, habría que admitir la presencia de Iyādíes también en la ciudad de Orihuela.

La expresión tuwuffiya («murió») aparece en la práctica totalidad de los epitafios andalusíes, sustituida en contadas ocasiones por māta. Tan sólo hay que destacar que por el lugar en que se ubica, inmediatamente detrás del nombre, se adelanta a lo que será frecuente en los epitafios a partir del siglo XII y, por otra parte, indica que este epitafio, como los otros dos de Orihuela, no pertenece al medio rural, pues en las lápidas procedentes de ese ámbito desaparece $h \bar{a} d \bar{a} q a b r$ y se incluye tuwuffiya tras la basmala y antes del nombre del difunto ${ }^{28}$.

La eulogia a favor del difunto raḥima-hu Allāh («Dios se apiade de él») es otro elemento muy frecuente en los epitafios andalusíes desde el principio, y eso frente a la aún escasa fijeza que presentan los formularios de época omeya en Oriente ${ }^{29}$,

${ }^{24} C f$. Fück, J. W., «Iyād», $E I^{2}$ IV(1978), 301-302.

${ }^{25}$ Ibn Hazm al-Andalusī, Ŷamharat ansāb al-'arab, ed. 'Abd al-Salām Muhammad Hārūn, El Cairo, 1982, 371.

${ }^{26}$ Ibid., 327-328. Sobre el poblamiento de Carmona en época islámica, y en especial sobre la presencia de Iyādíes, $c f$. Valencia, R., «La Cora de Carmona (712-1247): medio físico y humano», Actas del I Congreso de Historia de Carmona. Conmemorativo del 750 aniversario de la toma de Carmona por Fernando III. 1247. Carmona (Sevilla), 22 al 25 de septiembre de 1997, Sevilla, 1998, 39-42.

${ }^{27}$ Kitāb iqtibās al-anwār, 181.

${ }_{28}$ Barceló, Estructura textual, 48.

${ }^{29}$ Sobre la «libertad» en el uso de expresiones religiosas en los epígrafes omeyas más arcaicos, $c f$. Sourdel-Thomine, J., «Inscriptions et graffiti arabes d'époque umayyade. À propos de quelques publications récentes», Revue des Études Islamiques, XXXII, 1(1964), 115-120, especialmente, 119; y Ory, S., «Aspects religieuses des textes epigraphiques du début de l'Islam», Revue du Monde Musulman et de la Méditerranée, 58 (1990), 30-39. Hay que recordar que, en al-Andalus, la inscripción de la mezquita de Ibn 'Adabbas (Sevilla), del año 214 H., la más arcaica que se conserva, comienza, frente al formulario de textos fundacionales que se fijará con posterioridad, con una 
especialmente en los llamados graffiti ${ }^{30}$. En al-Andalus sólo está ausente en algunos casos puntuales ${ }^{31} \mathrm{y}$ en zonas concretas a partir de la tercera década del siglo XI y sobre todo en el siglo XII ${ }^{32}$. No obstante, en epitafios cordobeses ${ }^{33}$ de la primera mitad del siglo XII sí aparece, y tras tuwuffiya, orden frecuente en ese siglo.

En el epígrafe que nos ocupa, esta expresión se ubica asimismo tras tuwuffi$y a$, lo que es poco habitual para su cronología, pues en época califal esta eulogia suele aparecer tras el nombre del difunto ${ }^{34}$. Aunque en la zona levantina se documentan dos casos semejantes, de cronología califal ${ }^{35}$, más tardíos, sin embargo, que la lápida de Orihuela.

El formulario termina con la fecha, en la que se consigna el momento del óbito, feria de la semana, día del mes y año; es decir, una datación muy completa. En cuanto al año, he restituido el término sana, al comienzo del último renglón, por ser la expresión más habitual para indicar el año y porque así parece indicarlo la figura $15 f$ que acabaría ese término, tallado sobre el filete. Sin embargo, cabe también la posibilidad de que se trate del sinónimo 'àm, menos frecuente, dado el deficiente estado de conservación de esa parte del epígrafe.

Esta inscripción no incluye ninguna cita coránica ni eulogia de relación que sirva de cierre al epitafio, frente al uso asiduo de estos elementos en época califal. Un solo ejemplar procedente de Valencia, del año 345/956, tampoco ofrece fórmula de cierre ${ }^{36}$.

expresión propiciatoria en la que se incluye una variante de la raíz $R H M$ : yarḥamu Allāh a favor del emir 'Abd al-Raḥmān II. Cf. Ocaña Jiménez, El cúfico hispano, n. ' 1, lám. I.

${ }^{30}$ Como señala Solange Ory, no hay seguridad de si esta expresión y algunas de sus variantes se aplican en estos epígrafes a personas vivas o muertas, aunque apunta que probablemente a ambas; $c f$. Ory, S., «Les graffiti umayyades de 'Ayn Ğarr», Bulletin du Musée de Beyrouth, XX (1967), 144. Sobre el carácter de las inscripciones y graffiti de Jordania, $c f$. Imbert, F., «Inscriptions et graffiti arabes de Jordanie. Quelques réflexions sur l'établissement d'un récent corpus», Quaderni di Studi Arabi, 16 (1998), 48-58; y del mismo autor, «La nécropole de Qastal en Jordanie», Archéologie Islamique, 3 (1992), 17-59, donde afirma que en «epigrafía popular» el formulario evoluciona al margen de la epigrafía oficial (51). Ciertamente, en al-Andalus está documentado también el uso de algunas de esas expresiones que incluyen variantes de dicho lexema, especialmente en los graffiti, también denominados «escrituras espontáneas». $C f$. Barceló, C., «Los epígrafes árabes de Guardamar», en Azuar, R. (coord.), La rábita califal de las dunas de Guardamar, Alicante 1989, 183-197; y Sidarus, A., y Teichner, F., «Termas romanas no Gharb al-Andalus. As inscrições árabes de Milreu (Estói)», Arqueologia Medieval, 5 (1997), 177-189; aunque estos últimos los interpretan como textos funerarios.

31 Como en el epitafio procedente de Alcoi, del año 374/984. Barceló, La escritura árabe, n. ${ }^{\circ} 6,81$ y $133-135$.

32 Barceló, Estructura textual, 46.

${ }^{33}$ Martínez Núñez, M. a A., «Estelas funerarias de época almorávide aparecidas en Córdoba», Miscelánea de Estudios Árabes y Hebraicos, 45 (1996), 133-146.

${ }^{34}$ Barceló, Estructura textual, 46; y La escritura árabe, 81.

35 Barceló, La escritura árabe, n. ${ }^{\circ}$ 8, estela de Xabia (Alicante) fechada entre los años 380404/990-1014, y n. ${ }^{\circ} 11$, de Castellón, del año 403/1012. 


\section{ESTELA N..$^{\circ}$}

Estela de piedra arenisca, muy porosa, de forma rectangular y con los lados verticales más largos. La parte superior está muy deteriorada y ha perdido el filete que bordearía los cuatro lados de la estela. Sus medidas son: $54 \mathrm{~cm}$ de altura, $49 \mathrm{~cm}$ de anchura y $8 \mathrm{~cm}$ de grosor. El filete mide $1,5 \mathrm{~cm}$, aunque el lado horizontal inferior presenta un tamaño mayor: $4 \mathrm{~cm}$ en su parte derecha y $8,1 \mathrm{~cm}$ en la izquierda. El campo epigráfico ocupa toda la superficie de la estela y la última línea es más corta y alineada a la derecha, algo frecuente en lápidas rectangulares andalusíes ${ }^{37}$. Se conservan once líneas de escritura en cúfico austero tallado en relieve. De ellas, las seis primeras están muy gastadas, habiéndose conservado sólo pequeños fragmentos de algunas palabras, mientras que las cinco últimas presentan un buen estado de conservación (fig. 6, lám. 2).

\section{Lectura y traducción}

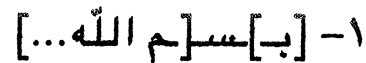

$$
\begin{aligned}
& \text { r- بإنيّها النّاس....وعد] الله } \\
& \text { ع } \\
& \text { ع- الدّّنـ] }
\end{aligned}
$$

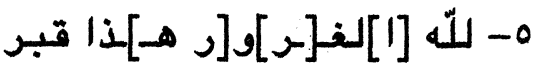

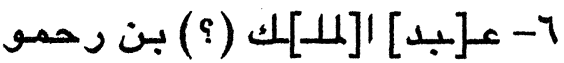

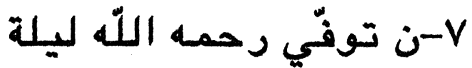

$$
\begin{aligned}
& \text { 1- الجمعة لخمسة عشر يو }
\end{aligned}
$$

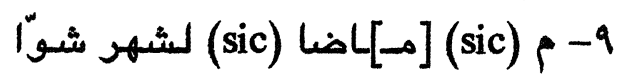

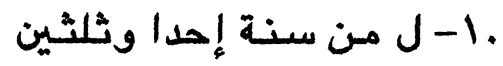

$$
\begin{aligned}
& \text { || } 1 \text { - وثلث مئة }
\end{aligned}
$$

En el nombre (de Dios..). ¡Oh (hombres!.....la promesa) de Dios es verídica.... la vida mundanal (y no os extravie) respecto de Dios el Seductor (Q. $\mathrm{XXXV}, 5)$. Este es el sepulcro de 'Abd al-Malik (?) ibn Raḥmūn, murió, Dios se apiade de él, la noche del viernes a quince días pasados del mes de šawwāl del año trescientos treinta y uno (jueves, 22 de junio del 943).

${ }^{36} \mathrm{Ibid} ., \mathrm{n} .{ }^{\circ}$ 5; sobre las fórmulas de cierre, 82; y Estructura textual, 49. 


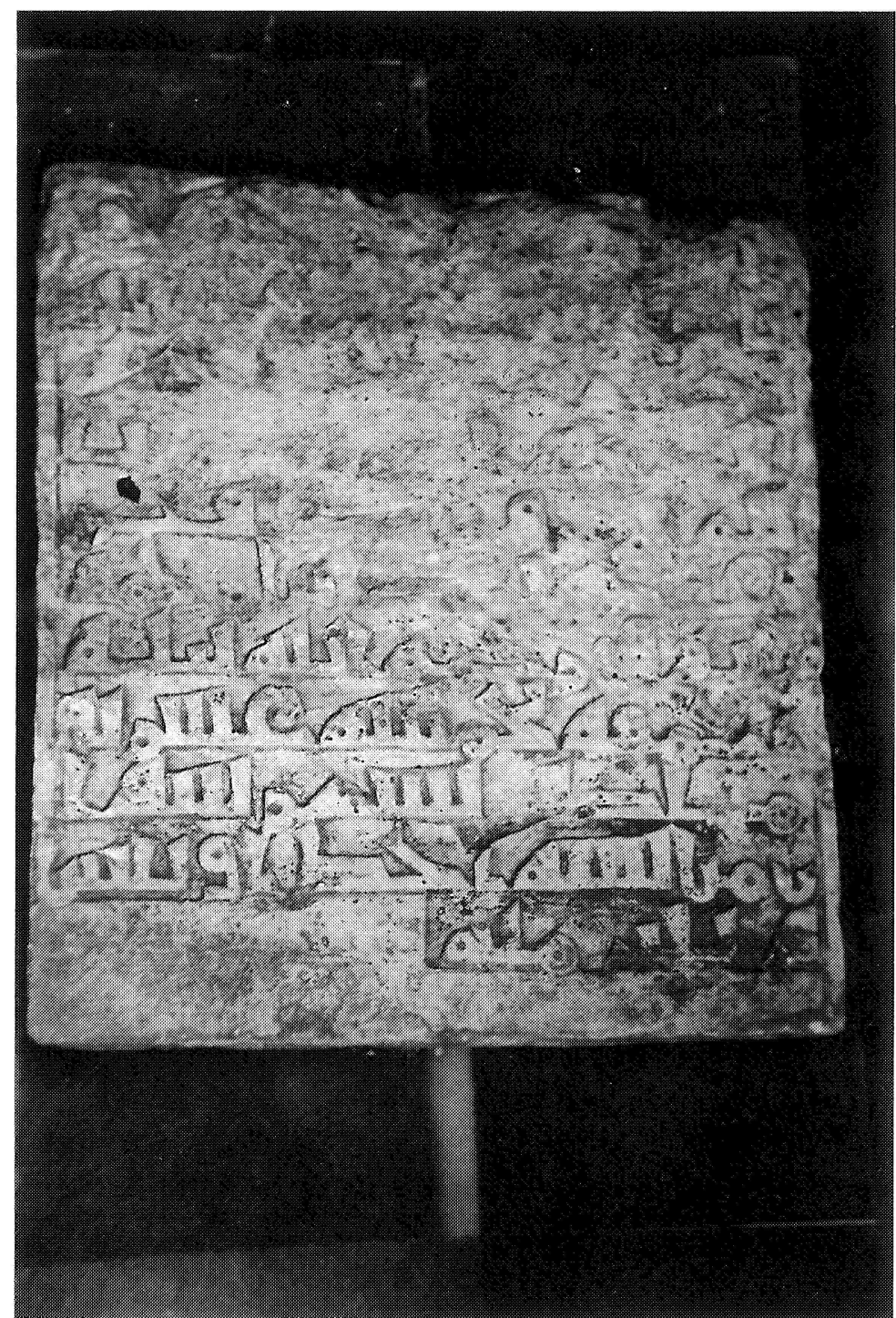

FiguRA 6. Reproducción fotográfica de la estela n. ${ }^{\circ} 2$. 


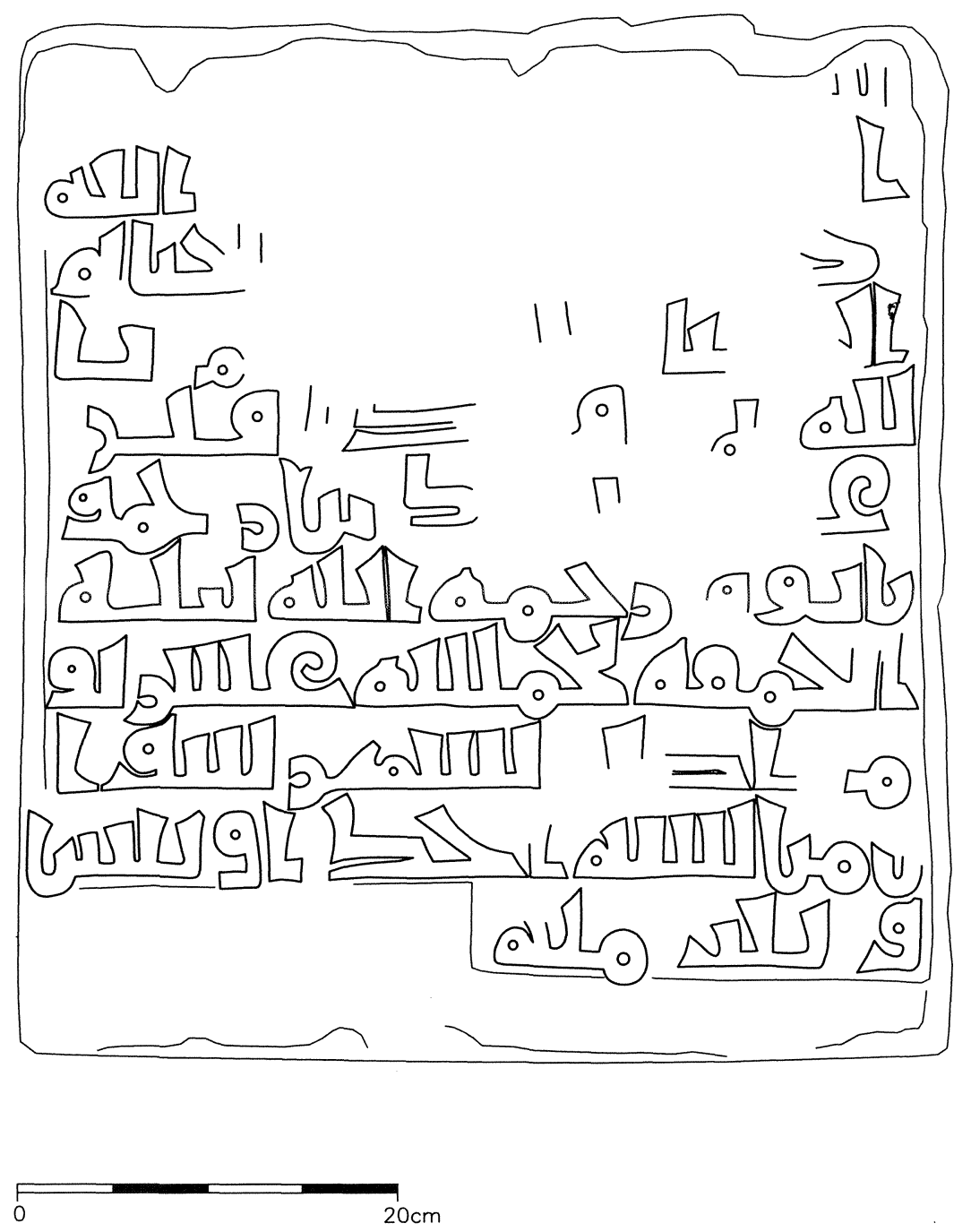

LÁminA 2. Dibujo de la estela n. ${ }^{\circ} 2$. 


\section{Análisis caligráfico}

El cúfico de esta estela, de una factura muy cuidada, es también de diseño arcaico y austero, pues no presenta ningún ornato en las terminaciones de los grafemas, frente al uso de esos elementos en inscripciones oficiales cordobesas de años precedentes, como la fechada en el año $329 \mathrm{H}^{38}{ }^{38}$, y en estelas funerarias de Córdoba, como el epitafio de 'Uqār del año $268 \mathrm{H}$. —el más antiguo en cúfico florido-y, de Almería, el de Ibn Bunāniyya, del año 312 H. ${ }^{39}$.

En general, el diseño de todos los grafemas responde, como en el epígrafe anterior, al que presenta el cúfico arcaico. No obstante, y a pesar de ser la más antigua de las tres estelas de Orihuela, se observa una diferenciación neta entre los trazos $5 \mathrm{f}$ y $14 \mathrm{f}$, pues el $n \bar{u} n$ final se presenta siempre con terminación ascendente, pero sin ningún ornato. Parece que esa forma de realizar la figura $14 \mathrm{f}$ no era habitual por esas fechas en la epigrafía funeraria levantina, y más específicamente en la de Alicante, pues la lápida de Alpatró, fechada en el mismo año $331 \mathrm{H}$., ya citada ${ }^{40}$, no presenta ese diseño, pero tampoco otros ejemplares de años posteriores. Sí aparece, sin embargo, en la lápida fundacional de una de las mezquitas de Guardamar (Alicante) ${ }^{41}$, del año 333/944.

Asimismo, el grafema 9i presenta en esta inscripción un diseño más evolucionado que el que adopta en el cúfico arcaico y se asemeja al realizado en la inscripción funeraria almeriense del $312 \mathrm{H}$., ya citada, y al que se observa en el cúfico florido de medios oficiales, como el de la lápida de la Puerta de las Palmas ${ }^{42}$ en la Mezquita de Córdoba, del año $346 \mathrm{H}$.

En cuanto a otros hechos de grafía, hay que destacar la separación de palabras entre renglones, tras grafemas que no se unen al trazo siguiente, en bi/llāh (4. ${ }^{\circ}$ y $5^{\circ}$ renglón), Raḥmū/n $\left(6 .^{\circ}\right.$ y $\left.7 .^{\circ}\right)$, yaw/m $\left(8 .^{\circ}\right.$ y $\left.9 .^{\circ}\right)$ y šawwā/l $\left(9 .^{\circ}\right.$ y $\left.10 .^{\circ}\right)$, práctica común, como acertadamente ha señalado Carmen Barceló ${ }^{43}$, en grafía cúfica lapidaria durante la Edad Media. Se ha escrito mā ḍa por el habitual maḍà y sustituido, como en el término anterior, alif maqșūra por mamdūda en ị̣dà. Talät y mi'a aparecen con escritura defectiva, hecho frecuente en epigrafía andalusí y levantina ${ }^{44}$.

37 Barceló, La escritura árabe, 62.

${ }^{38}$ Lévi-Provençal, Inscriptions, n. ${ }^{\circ}$ 5, pl. IIa.

39 Ocaña Jiménez, El cúfico hispano, n. ${ }^{\circ} 5$ y 9, lám. V y IX, 26 y 28 , respectivamente; y del mismo autor, Repertorio, n. ${ }^{\circ}$, lám. 1a. El epitafio almeriense del 312 H. es también el ejemplar más arcaico de esa procedencia.

40 Cf. supra, nota 17.

41 Barceló, La escritura árabe, n. ${ }^{\circ}$ 3, lám. IIIa y IIIb, 128-130.

42 Ocaña Jiménez, El cúfico hispano, 23, n. ${ }^{\circ} 16$, lám. XVI, fig. 6.

43 Barceló, La escritura árabe, 104-105. 


\section{Análisis textual}

Por las medidas que conserva la estela, no ha debido perderse mucho del texto original. El primer renglón de los conservados resulta ilegible, salvo el trazo $6 \mathrm{~m}$, por lo que cabe la posibilidad de que fuese efectivamente el principio del texto y que incluyera la basmala, fórmula inicial fija en los epitafios andalusíes de esa cronología. Los renglones segundo al quinto se encuentran muy deteriorados, aunque, por los restos gráficos conservados, estimo que se puede restituir la aleya XXXV, 5; la cita coránica más utilizada en los epitafios andalusíes ${ }^{45}$. El texto restituido de esa aleya es:

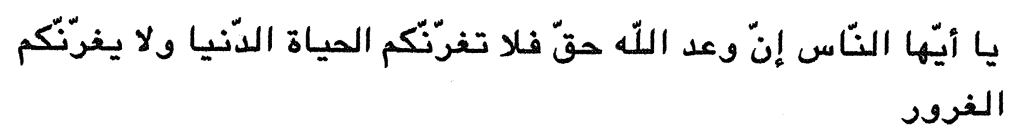

¡Oh hombres! La promesa de Dios es verídica. Que no os extravíe la vida mundanal ni os extravie respecto de Dios el seductor.

Del comienzo de esta cita sólo se perciben los trazos 17i y 1f, por lo que podría haberse tallado يايّها, como un caso de haplografía frecuente en el cúfico andalusí y, según Carmen Barceló ${ }^{46}$, también en el levantino.

Si se dan por válidas estas consideraciones, el orden del formulario sería:

1) Basmala.

2) Cita coránica.

3) La expresión hā $\underline{a} a \bar{a} q a b r$.

4) Nombre del difunto.

5) Tuwuffiya.

6) Eulogia rạ̣ima-hu Allāh.

7) Fecha.

Esto implica que no se incluiría la šahāda en el formulario, al igual que ocurre en la mayor parte de los epitafios levantinos de época califal ${ }^{47}$ y en lápidas de Denia y Alpuente de las décadas 1030 a $1060^{48}$.

${ }^{44}$ Barceló, ibid., 100.

45 Barceló, Estructura textual, 45.

${ }^{46}$ Ibid., 100

47 Barceló, La escritura árabe, 81

${ }^{48}$ Barceló, Estructura textual, 48. 
También supone que la tan utilizada cita coránica XXXV, 5 aparecería aquí tras la basmala y antes de $h \bar{a} \underline{\underline{d}} \bar{a} q a b r$. Ese orden altera la secuencia conocida para las estelas levantinas de cronología califal. Y así, en la inscripción de Alpatró del $331 \mathrm{H}$. y en la procedente de Les Alcusses, Moixent (Valencia) ${ }^{49}$, del año 339/950, el orden es el mismo: basmala, seguida de $h \bar{a} d \bar{d} a$ qabr y como cierre del formulario Q. XXXV, 5. En epitafios andalusíes dicho fragmento coránico se introduce sistemáticamente tras la basmala a partir del siglo XI, aunque existen algunos precedentes de ese uso en el siglo anterior ${ }^{50} \mathrm{y}$ se documenta por primera vez en la inscripción almeriense del año $312 \mathrm{H}$., pues aunque la estela está fragmentada, la cita coránica se ubica inmediatamente antes de $h \bar{a} d \bar{a} q a b r^{51}$.

En cuanto al orden en que aparecen los elementos hāda qabr, tuwuffiya y rahima-hu Allāh, es el mismo que el de la inscripción precedente, por lo que remito al análisis antes realizado.

La mención del nombre del difunto consigna solamente un ism, 'Abd alMālik, muy común en onomástica árabo-islámica, y un nasab, ibn Raḥmūn, compuesto por un nombre del tipo Farḥūn, Salmūn, Hamdūn, Sa'dūn, Badrūn, Galbün, Furtūn, Lubbün, etc. Estos nombres abundan en antroponimia árabe, especialmente en al-Andalus, y tienen en común el sufijo -ūn, documentado, junto a otros sufijos, en nombres propios considerados como hipocorísticos ${ }^{52}$. En el caso específico de Rạ̣mūn, y aunque he podido documentar el ism y el nasab en algún caso ${ }^{53}$, es preciso concluir que era muy poco habitual en antropónimos andalusíes.

La fecha cierra el formulario, como en el epígrafe $n .^{\circ} 1$, sin eulogia ni cita coránica final, e incluye las mismas precisiones.

49 Barceló, La escritura árabe, n. ${ }^{\circ} 4,130-132$.

50 Barceló, Estructura textual, 45, donde cita dos lápidas almerienses de los años 932 y 956 , una mallorquina del 968 y otra murciana del 972.

51 Ocaña Jiménez, El cúfico hispano, n. ${ }^{\circ}$ 9, lám. IX; y Repertorio, n. ${ }^{\circ} 1$, lám. 1a.

52 García Gómez, E., «Hipocorísticos árabes y patronímicos hispánicos», Arabica, 1 (1954), 129-135; quien se basa en el artículo de E. Littmann, «Arabische Hypokoristika», sobre los nombres propios árabes de Oriente Medio. Para la época de esta lápida, $c f$. Marín, M., «Onomástica árabe en al-Andalus», Al-Qantara, IV (1983), 144.

53 En relación con una anécdota, referida a la biografía de al-Bațalyawsī, se cita a los hijos del șāhib Qurtuba Ibn al-Hầŷy, cuyos nombres eran: 'Azzūn, Raḥmūn y Hassūn, sobre los que dicho gramático compuso un poema; $c f$. al-Suyūțī, Bugyat al-wu'āt fi tabaqà̃t al-lugawiyyìn wa-l-nuhāt, ed. M. Abū 1-Faḍl Ibrāhīm, vol. 2, Beirut 1979, 55-56; y se incluye asimismo la mención de un gramático, con nisba beréber, 'Abd al-Raḥmān ibn Muḥammad ibn 'Abd al-Raḥmān Abū l-Qāsim ibn Raḥmūn al-Maṣmūdī (m. 694 H.); ibid., 86. Un caid de Timzugt, de época del meriní Abū l-Hasan, es nombrado como Mūsà ibn 'Īsà ibn Rạ̣mūn; $c f$. Ibn Marzūq, El Musnad: hechos memorables de Abū l-Hasan, sultán de los benimerines. Estudio, trad., anotación e índices de M. ${ }^{\mathrm{a}} \mathrm{J}$. Viguera, Madrid, 1977, 405. 


\section{ESTELA N. 3}

Estela de piedra arenisca de forma rectangular, con los lados horizontales más largos que los verticales. El campo epigráfico, que ocupa todo el frontal de la lápida, aparece bordeado de un filete tallado en relieve. El lado horizontal superior ha perdido esa moldura de enmarque, pero se conserva el texto íntegro, por la aparición en el primer renglón de la fórmula introductoria de la basmala, aunque muy deteriorada. Sus medidas son $44 \mathrm{~cm}$ de altura, $60,5 \mathrm{~cm}$ de anchura y $12 \mathrm{~cm}$ de grosor, y el filete, $2,5 \mathrm{~cm}$ en su medida máxima. Contiene siete líneas de escritura en cúfico austero tallado en relieve, en muy mal estado de conservación, lo que no ha impedido restituir la mayor parte del texto. Las tres últimas líneas presentan los caracteres más comprimidos que las superiores, especialmente las dos primeras (fig. 7, lám. 3).

Lectura y traducción

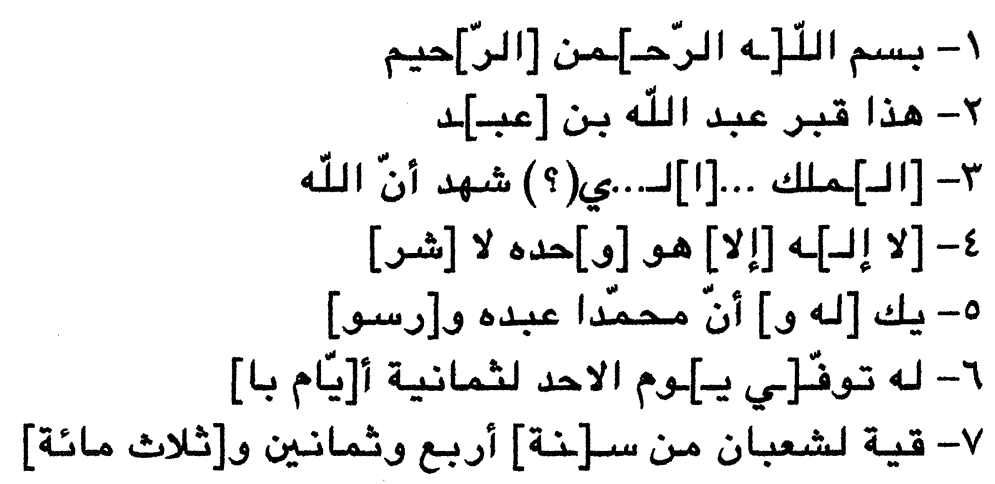

En el nombre de Dios, el Clemente, el Misericordioso. Este es el sepulcro de 'Abd Allāh ibn 'Abd al-Mālik...al-..., y él dio testimonio de que Dios, no hay más divinidad que Él, Él solo, no tiene asociado, y que Muhammad es Su siervo y Su enviado. Murió el diurno del domingo a ocho días quedantes de ša 'bān del año (trescientos) ochenta y cuatro (miércoles, 22 de agosto del 994).

\section{Análisis caligráfico}

Esta inscripción de finales del siglo $\mathrm{x}$, la más tardía, presenta también, y a pesar de ello, un cúfico de rasgos arcaizantes. Así, no aparece ningún nexo cur- 


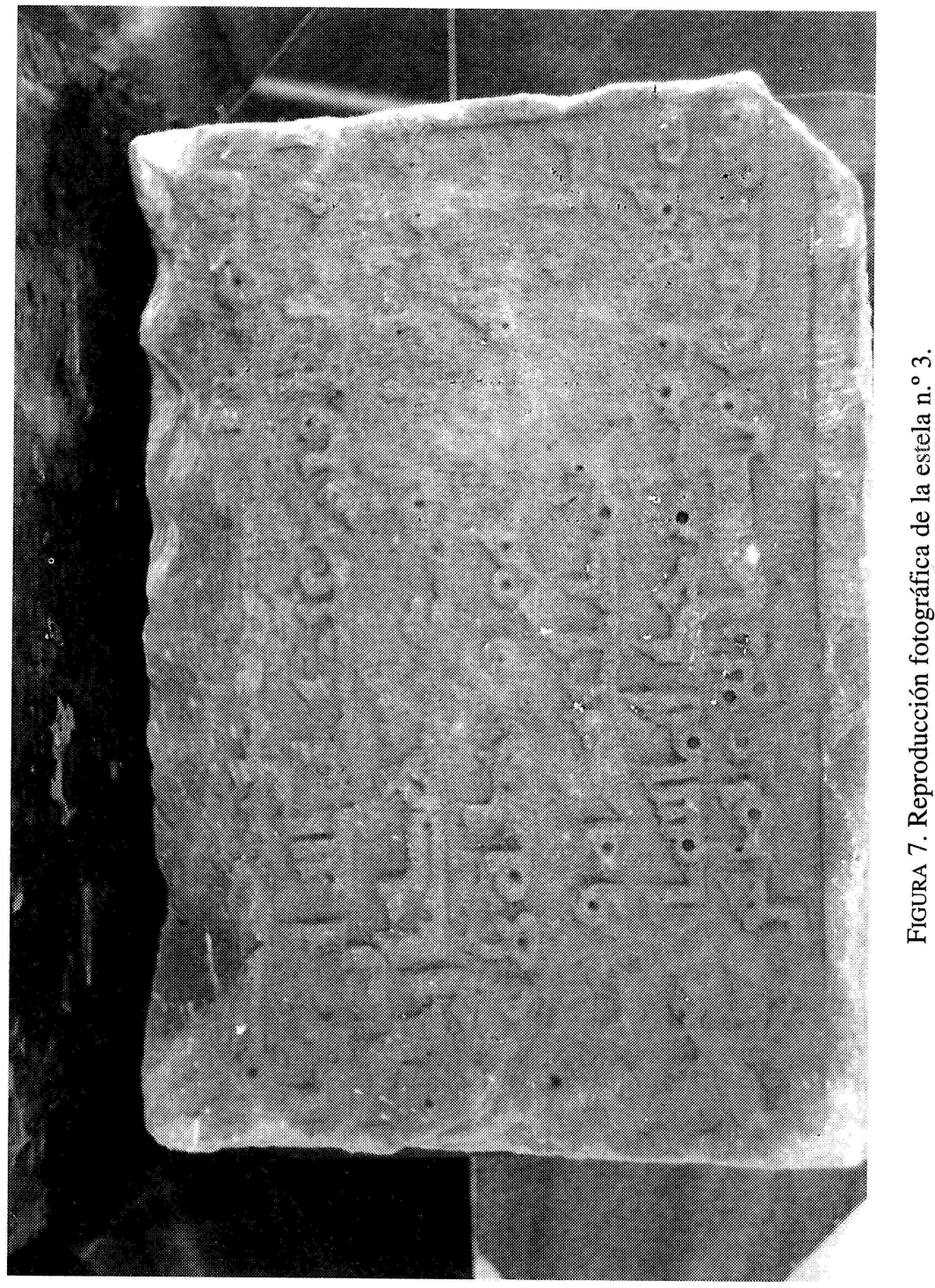




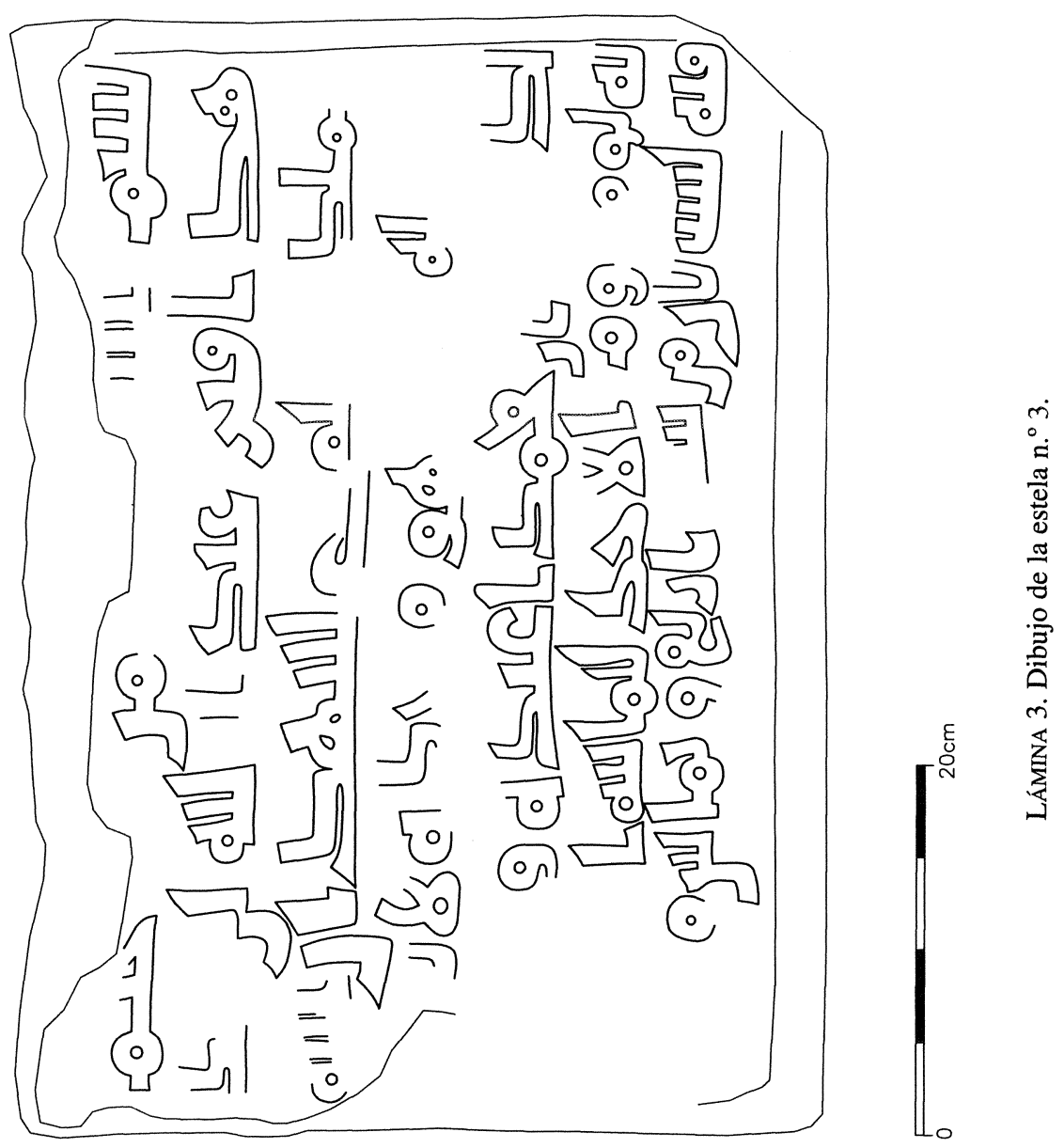


vo por debajo de la línea de base y los trazos $2 \mathrm{i}$ y $\mathrm{m}$. y $12 \mathrm{i}$ y m. se diferencian en su altura. Sin embargo, es posible que en la basmala sí se produzca esa identificación; extremo que no se puede establecer con seguridad por el deterioro de la parte superior del primer renglón. El grafema $14 \mathrm{f}$ presenta diseño austero, sin prolongación ascendente, pero se distingue del 5f., y el nexo lām-alif, así como el término Allāh coinciden con los realizados en el cúfico arcaico y en las dos estelas precedentes.

El mantenimiento de un cúfico arcaico, o arcaizante, en la zona levantina contrasta con lo que acontecía en Córdoba y en otras zonas de al-Andalus en la segunda mitad del siglo Iv $\mathrm{H}$. En la epigrafía oficial de Córdoba se había impuesto, ya desde el año $353 \mathrm{H} .{ }^{54}$, el llamado «cúfico simple», característico de la época del califa al-Hakam II y que pervivirá en determinadas regiones andalusíes tras la caída del califato; un cúfico sin ornatos florales ni foliados, pero muy evolucionado en su diseño y en el que se habían afianzado y extendido los cambios introducidos en la etapa precedente.

Hay que destacar, como características más evolucionadas, la forma en que se ha realizado la figura 13i en el término Muhammad (renglón 5..$^{\circ}$ ), montando sobre el trazo oblicuo del grafema $3 \mathrm{~m}$, muy semejante a la que presenta la inscripción fundacional de la mezquita de Guardamar, ya citada ${ }^{55}$, del año $333 \mathrm{H}$., y diferenciado de la factura de ese mismo término en la estela n. ${ }^{\circ} 1$. El grafema $15 \mathrm{i}$ y m., en $h \bar{a} \underline{d} \bar{a}, \grave{s} a h \bar{a} d a$ y huwa, sin dejar de tener un aspecto arcaizante, adopta también - y frente a la forma de esa figura en las dos estelas anteriores y en otros epitafios levantinos - un diseño especial, apuntado y con un pequeño apéndice en su parte superior, pero conserva la rigidez de la línea de base, a semejanza de lo que sucede en la inscripción de la alcazaba de Mérida y en el epitafio cordobés de Gadịira ${ }^{56}$, de año $241 \mathrm{H}$., antes mencionados. Y los trazos 12/2/14/17 consecutivos y $6 \mathrm{i}$ y $\mathrm{m}$. se han ejecutado con altura decreciente.

Por último se observa, como en los casos anteriores y en las mismas circunstancias, la separación entre renglones de šarlïka ( $4 .^{\circ}$ y $5 .^{\circ}$ renglón), rasūllu-hu $\left(5^{\circ}\right.$ y $\left.6 .^{\circ}\right)$ y bălqiya $\left(6 .^{\circ}\right.$ y $\left.7 .^{\circ}\right)$, y grafía defectiva en ilāha.

\footnotetext{
54 Año en el que están fechados los epígrafes de los capiteles del alcázar de Córdoba. $C f$. Ocaña Jiménez, El cúfico hispano, n. ${ }^{\circ}$ 19, lám. XIX, 35.

${ }^{55}$ Cf. supra, nota 40.

${ }^{56}$ Ocaña Jiménez, El cúfico hispano, 24, fig. 2 y n. ${ }^{\circ} 4$, lám. IV, respectivamente.
} 
Análisis textual

El texto de esta inscripción está virtualmente completo, a pesar de su mal estado de conservación. Sus elementos son:

1) Basmala.

2) $H a \bar{d} \underline{a} q a b r$.

3) Nombre del difunto.

4) Šahāda.

5) Término tuwuffiya.

6) Fecha.

$\mathrm{El}$ orden de los diversos componentes del formulario altera el que presentan las dos inscripciones anteriores y, frente a éstas, no introduce ninguna cita coránica, aparte de la šahāda.

En ese sentido, llama la atención que, siendo la inscripción de Orihuela de cronología más tardía, coincida en la secuencia de los tres primeros elementos del formulario con los ejemplares más antiguos de la zona levantina; en realidad, con la secuencia que Carmen Barceló establece para los epitafios de época califal ${ }^{57}$ y que también observa en estelas cordobesas de la etapa emiral ${ }^{58}$. Pero, a diferencia de esos epitafios, no incluiría la eulogia raḥima-hu Allāh tras el nombre del difunto, pues los restos conservados inmediatamente antes de la šahāda (renglón 3..$^{\circ}$ ) parecen indicar la inclusión de una nisba. La supresión de la eulogia rahima-hu Allāh es poco habitual en epitafios andalusíes, aunque se observa también en un ejemplar de Alcoi del año 374/984 y en algunas zonas de al-Andalus, especialmente en el siglo XII, como ya adelanté al analizar la estela n. ${ }^{\circ} 1$ (ver notas 31 y 32 ).

Sin embargo, en esta inscripción se incluye la šahāda, en forma de introducción, tahlīl completo y risāla completa: šahada anna Allāh lā ilāha illà huwa waḥda-hu lā šarika la-hu wa-anna Muhammad 'an 'abdu-hu wa-rasūlu-hu; hecho habitual en la epigrafía funeraria cordobesa de las épocas emiral y califal, pero infrecuente en los epitafios levantinos de cronología califal, como señala Carmen Barceló y ya adelanté al analizar la estela $n .^{\circ} 1^{59}$.

57 Barceló, La escritura árabe, 81. Ese orden aparece en los epitafios n. 2 y n. 4 (127 y 131), los más arcaicos, pero también en el $n .^{\circ} 8$ (138), sin fecha, pero datado entre los años 380 y $404 \mathrm{H}$., por sus rasgos epigráficos, y en el n..$^{\circ} 10$ (141), del año 401/1011.

58 Como el de la Umm walad Badí', del último cuarto del siglo III H., procedente de Córdoba y conservado en el Museo de Málaga. $C f$. Lévi-Provençal, Inscriptions, n. ${ }^{\circ}$ 3, 3-4; y Acién Almansa y Martínez Núñez, Catálogo, n. ${ }^{\circ}$ 2, 21-22. Y, asimismo, en los recogidos por Ocaña Jiménez, El cúfico hispano, n. ${ }^{\circ}$ 3, 4 y 5.

59 Cf. supra, nota 18. 
Ahora bien, la introducción de la šahāda - vaya o no seguida de cita coránica- entre el nombre del difunto — seguido o no de rahima-hu Allăh - y tuwuffiya, como en este caso, se observa en algunos epitafios cordobeses de época emiral y califal ${ }^{60}$. En otras zonas de al-Andalus se repite ese mismo orden a partir del siglo $\mathrm{XI}^{61} \mathrm{y}$, asimismo, en el país valenciano durante la época de taifas ${ }^{62}$, con la salvedad de que esos epitafios levantinos suelen incluir rahima-hu Allăh tras tuwuffiya.

En consecuencia, se puede afirmar que el formulario de esta inscripción se aproxima al utilizado en Córdoba en los siglos III y IV H., que al más usual de la región valenciana durante el período califal, en el que suele estar ausente la šahàda completa. En ese sentido, sería un precedente del formulario empleado en algunos epitafios del siglo siguiente.

La onomástica del difunto incluye un ism, 'Abd Alläh (2. ${ }^{\circ}$ renglón), un nasab, ibn 'Abd al-Malik (renglón 2. y 3.'), algún otro elemento perdido por rotura y una posible nisba (renglón $3 .^{\circ}$ ), pues se detecta el trazo $12 \mathrm{i}$ del artículo, seguido del grafema $10 \mathrm{~m}$ o $13 \mathrm{~m}$ y, tras una zona fragmentada e ilegible, la figura $17 \mathrm{f} \mathrm{o}$ a. Sin embargo, considero muy aventurado plantear, a partir de esos elementos, una hipótesis de lectura que resulte medianamente fiable.

Carmen Barceló ha apuntado la posibilidad de que el ism 'Abd Allāh -presente en los epitafios más antiguos, estudiados por ella, como nombre del padre y del abuelo- pueda estar en relación con el proceso de conversiones al islam en la zona ${ }^{63}$. En el caso de Orihuela, opino que sería posible extender también esa hipótesis al ism 'Abd al-Malik, pues aparece en la inscripción más antigua como nombre del difunto y en la más tardía como nombre del padre, sin haber podido precisar en este último caso el tipo o el carácter de la nisba.

Con respecto a la fecha, donde sólo he restituido la centena, cierra el formulario, como en los casos anteriores.

\footnotetext{
${ }^{60}$ Como en el epitafio de 'Uqār del 268 H., y en el de una mujer del 294 H.; cf. Ocaña Jiménez, El cúfico hispano, n. 5 y 8; o en el de Badī', fechado a finales del siglo III, y el del año $328 \mathrm{H}$., conservados ambos en el Museo de Málaga. Acién Almansa y Martínez Núñez, Catálogo, n. ${ }^{\circ} 2$ y 4, 21-24. En el epitafio del año 328 rahima-hu Allāh va tras tuwuffiya.

${ }^{61}$ Como en Toledo, en el epitafio del año 421/1030. Lévi-Provençal, Inscriptions, n. ${ }^{\circ} 55$.

62 Como en la estela de Xàtiva del año $422 / 1031$ y en dos de Valencia, de los años 425/1034 y 453/1061. Barceló, La escritura árabe, n. ${ }^{\circ} 12,14$ y 20, 145, 148 y 160, respectivamente.

${ }^{63}$ Ibid., 81 .
} 


\section{VALORACIÓN FINAL}

Las tres estelas de Orihuela están realizadas en el mismo material, piedra arenisca, muy corriente en toda la zona levantina y casi exclusivo durante los siglos $\mathrm{x} \mathrm{y} \mathrm{XI}{ }^{64}$. Las tres presentan talla en relieve, lo que es también habitual en la mayor parte de los epitafios valencianos, y otro tanto se puede decir de la distribución del campo epigráfico, que ocupa toda la zona frontal y aparece bordeado de un estrecho filete, algo más amplio en la parte inferior, igual que los ejemplares más arcaicos hallados hasta el momento ${ }^{65}$.

En cuanto a la forma de las estelas, son rectangulares, pero mientras que las dos primeras presentan los lados verticales más largos, ateniéndose a lo que Carmen Barceló ha denominado como «forma estándar» en al-Andalus, en la n. ${ }^{\circ} 3$ los lados más largos son los horizontales. Esa forma apaisada sólo se habría documentado con seguridad, hasta ahora, en una estela procedente de Almería, del año $488 / 1095^{66}$.

Sin embargo, la tipología que presentan las estelas de Orihuela se aparta de la que Carmen Barceló describe para la zona alicantina durante el siglo $\mathrm{x}:$ «El rectángulo se estrecha por el pie, dando a la estela una figura casi trapezoidal», y más adelante añade: «Es probable que este tipo de estelas se colocaran sobre el suelo (...) encajadas en algún tipo de pie» ${ }^{67}$. Esta hipótesis sobre la ubicación de las estelas es perfectamente aceptable para las que presentan dicho estrechamiento en la parte inferior, anepígrafa, y puede verse corroborada por las estelas conservadas en el Ribat de Soussa ${ }^{68}$, pero hay que descartarla en el caso de las estelas con la superficie entera epigrafiada, como las de Orihuela.

Para este último caso yo plantée, al estudiar unos ejemplares de época almorávide procedentes de Córdoba, que debieron de contar con tabicas laterales o con cualquier otro elemento de soporte ${ }^{69}$. Por su parte, Carmen Barceló sugiere que tal vez se colocaban «empotradas en alguna pared hecha al efecto o se apoyaban por detrás en una peana o un murete» ${ }^{70}$.

${ }^{64}$ Ibid., 65 .

${ }^{65}$ Ibid., 62, 68 y 71 .

${ }^{66}$ Ibid., 65.

67 Ibid., 69.

${ }^{68}$ Se trata de un lote de estelas tardías, de época otomana, pero recuerdan las procedentes de la rawḍa de la Alhambra y que servían de soporte a mqābriyya/s. Son anepígrafas, están profusamente decoradas y presentan una o dos ranuras para encajar estelas verticales. $C f$. Kouraïchi, S. «Analyse du décor d'une collection de pierres tombales conservée au Ribāt de Sousse», Archéologie Islamique, 8-9 (1999), 177, nota 1, y 201, fig. 15.

${ }^{69}$ Martínez Núñez, M. ${ }^{2}$ A., «Estelas funerarias de época almorávide», 135.

${ }^{70}$ Barceló, La escritura árabe, 69. 
Esa parece ser la ubicación de la estela de Orihuela n. $^{\circ}$ 2, embutida entre los sillares del muro y de la $n .^{\circ} 3$, en el interior, apoyada sobre el muro opuesto. Sin embargo, se da la circunstancia de que se trata de una construcción funeraria, identificada como mausoleo, pero cuyas dimensiones permitirían más bien su identificación con un gran sarcófago; un tipo de enterramiento que constituye un caso excepcional en cementerios andalusíes, especialmente en los de una cronología tan antigua como la que aportan estos epígrafes ${ }^{71}$, por lo que permanece la incógnita sobre la forma más habitual de colocar este tipo de estelas.

Por otra parte, desconocemos todo acerca de la posible ubicación original de la estela $n^{\circ} 1$, como ya se ha mencionado, y con respecto a la estela $n^{\circ} 3$, parece haber sido reutilizada, pues de otro modo no se explicaría el hecho de que la cabeza del cadáver infantil esté apoyada sobre la mitad inferior de la estela, tapando el epígrafe. Por consiguiente, no debía ser ésa su ubicación original. En este caso hay que pensar en la reutilización en un enterramiento posterior, también musulmán, de la estela; posibilidad que parece confirmarse por la existencia de varias fases de enterramientos sucesivos, y especialmente porque en algunos de estos enterramientos los cadáveres aparecen situados sobre los propios muros de la estructura funeraria.

El hecho de que la estela n..$^{\circ}$-la única que parece haberse conservado in situ - se encuentre tan cerca de la muralla y de cara a ella podría deberse a la construcción posterior de la muralla, lo que también explicaría que la maqbara se ubique intramuros.

En cuanto a la cronología de la muralla, de las fases posteriores de reutilización de la maqbara y del momento de su abandono, únicamente podrán ser determinados por los datos de la excavación. Aunque, en ese sentido, se puede recordar la cita que aporta al-'Ud́rī sobre un terremoto ocurrido en el año 440/1048-49, que destruyó la ciudad, derrumbando sus edificios altos y la mezquita $^{72}$, y que, según Carmen Barceló ${ }^{73}$, hubo de afectar a sus necrópolis.

En otro orden de cosas, las tres inscripciones del siglo x están realizadas en cúfico arcaico, como la mayor parte de los epígrafes levantinos de cronología califal; un cúfico que se diferencia del realizado por esas fechas en la epigrafía oficial y funeraria de Córdoba y de alguna que otra zona de al-Andalus. Esa constatación, junto al material utilizado, puede indicar que las estelas se labraron

\footnotetext{
71 Sólo se documenta un caso semejante en el cementerio de la Suda de Tortosa: la asociación de un epitafio del $349 \mathrm{H}$. con una estructura funeraria exenta, en cuyas proximidades apareció. $C f$. Yzquierdo, P., «Làpida funerària del governador 'Abd al-Salām B. 'Abd Allāh B. Basīl», en L'Islam i Catalunya. Catàleg, Barcelona, 1998, n. ' 24, 48-49.

72 Diz Ardid, Espacios urbanos, 166-167.

${ }^{73}$ La escritura árabe, 52.
} 
en cualquiera de los talleres levantinos. Sin embargo, los rasgos específicos, tanto caligráficos como textuales, que presentan en relación a otras inscripciones de esa región y de la misma cronología, inducen a pensar en la posibilidad de que fueran realizadas en talleres locales. Y no sólo eso, sino que existen diferencias entre ellas -en cuanto a la forma (la n. ${ }^{\circ} 3$ ), rasgos caligráficos específicos en cada una de ellas y contenido y orden de los elementos del formulario- de las que es posible inferir la existencia de diversos talleres locales, ya que, si estas divergencias podrían explicarse, en el caso de la estela n. $^{\circ} 3$, por el período de tiempo transcurrido con respecto a las dos anteriores, 49 años, no sucede lo mismo con las que presentan la $n .^{\circ} 1$ y la $n^{\circ} 2$, entre las cuales solamente median cuatro años.

Por otra parte, la existencia de estas tres magníficas lápidas funerarias del siglo $\mathrm{X}$, con un ejemplar de la misma fecha, año $331 \mathrm{H}$., que es el más arcaico conocido hasta ahora en el área levantina y otro del año $335 \mathrm{H}$., que sería el segundo en antigüedad, supone la primera constatación arqueológica del carácter urbano de Orihuela, al menos, desde comienzos del siglo X.

$\mathrm{Y}$ es que, si bien es cierto que las fuentes árabes citaban a Orihuela como una de las siete ciudades del pacto de Tudmīr ${ }^{74}$, también lo es que la designaban ambiguamente como madina y como ma qil y hiṣn ${ }^{75}$, lo que ha hecho cuestionar el carácter urbano de Orihuela entre los siglos vIII y x, sobre todo por la ausencia de restos arqueológicos anteriores a la segunda mitad del siglo $\mathrm{x}^{76}$.

Pues bien, el hallazgo de estas estelas corrobora, en mi opinión, la existencia de un cementerio de relieve y de ámbito urbano, y ello por varias razones: en primer lugar, por la monumentalidad de las estructuras funerarias que ha aportado; un caso excepcional, como ya se ha mencionado, para esa cronología, y porque se trata de un lote importante de estelas funerarias, si lo comparamos con el escaso número de ejemplares de esa cronología aparecidos en otros lugares del Levante y si se tiene en cuenta que la utilización de estelas epigrafiadas en necrópolis andalusíes es un hecho, en cierta medida, esporádico. En segundo lugar, la talla en relieve que presentan es la habitual en los epitafios de zonas urbanas,

\footnotetext{
${ }^{74}$ Gutiérrez Lloret, S., La cora de Tudmïr de la antigüedad tardía al mundo islámico. Poblamiento y cultura material, Madrid-Alicante 1996, 227-228.

75 Así, Ibn Hayyān, Muqtabis V, ed. P. Chalmeta, F. Corriente y M. Subh, Madrid, 1979, 128, cita a Orihuela como la más antigua de las ciudades (mudun) de la cora de Tudmīr, la más inexpugnable de sus fortalezas (amna' ma'āqili-hā) y como hịisn; y al-Rušāṭī, Kitāb iqtibās, 20, como una de las siete ciudades de Tudmīr y uno de sus ma'àqil.

76 Gutiérrez Lloret, La cora de Tudmir, 228; y Azuar Ruiz, R., y Gutiérrez Lloret, S. «Formación y transformación de un espacio agrícola islámico en el sur del País Valenciano. El Bajo Segura (siglos IX-XIII)», Castrum, 5, Archéologie des espaces agraires méditerrannéens au Moyen Âge, Madrid, Roma, Murcia, 1999, 203.
} 
frente a la labra incisa de un buen número de inscripciones funerarias procedentes de medios rurales; dato aún más significativo si se contempla la posibilidad de que fueran realizadas en distintos talleres locales. Y, en tercer lugar, el formulario de estas estelas remite también al empleado en los epitafios de ámbito urbano.

Por último, y aunque no he podido documentar la identidad de los difuntos, la onomástica consignada en una de las estelas, que incluye sólo ism -el teóforo muy común 'Abd al-Malik — y el nasab Ibn Rạ̣mūn, sin más elementos, tal vez pueda indicar que se trata de un muwallad, de un converso al islam, frente a lo que sucede en la estela $n .^{\circ} 1$ que consigna, aparte de algunos elementos perdidos, ism, nasab y una nisba tribal de origen árabe- y quizás también en el caso de la estela n. ${ }^{\circ}$, aunque el desconocimiento de la nisba no permita afirmarlo.

\section{RESUMEN}

El presente artículo tiene como objetivo la traducción y el estudio de tres inscripciones funerarias aparecidas en Orihuela (Alicante) en el curso de unas excavaciones arqueológicas. Se trata de las primeras estelas que aporta esta ciudad y que proceden con seguridad de ella. Todas ellas, aunque están bastante deterioradas, han conservado la fecha y tienen una cronología del siglo IV/x.

\section{AbSTRACT}

The present article has as its main aim the translation and study of the three funerary inscriptions found in Orihuela (Alicante) during the course of some diggings. These are the first steles found in this city that definitely belong to Orihuela. All of them, although they are quite damaged, have preserved the date and they belong to the 4th H./10th A.D. century. 